\title{
Uromodulin Biology and Pathophysiology - An Update
}

\author{
Petr Vyletal ${ }^{a, b}$ Anthony J. Bleyer ${ }^{c}$ Stanislav Kmoch ${ }^{a, b}$ \\ ${ }^{a}$ Center for Applied Genomics and ${ }^{\mathrm{b}}$ Institute for Inherited Metabolic Disorders, First Faculty of Medicine, \\ Charles University in Prague and General University Hospital in Prague, Prague, Czech Republic; \\ 'Section on Nephrology, Wake Forest University School of Medicine, Winston-Salem, N.C., USA
}

\section{Key Words}

Uromodulin · Tamm-Horsfall protein $\cdot U M O D \cdot$ Kidney •

Nephropathy $\cdot$ Urine $\cdot$ Loop of Henle $\cdot$ Hyperuricemia .

Determination

\begin{abstract}
Uromodulin (UMOD) is a glycoprotein expressed on the luminal surface of the apical membrane of renal tubular epithelial cells forming the thick ascending limb of Henle. Here, UMOD forms filamentous structures probably ensuring water impermeability and the countercurrent gradient. The multidomain structure, cellular topology of UMOD and clinical consequences associated with UMOD dysfunction, however, suggest that it may be involved in other biological processes such as receptor-mediated endocytosis, mechanosensation of urinary flow, Wnt-signaling, cell cycle regulation and planar cell polarity. A specific, but as yet unidentified, protease(s) releases UMOD into the urine, where it probably contributes to colloid osmotic pressure, retards passage of positively charged electrolytes, prevents urinary tract infection and modulates formation of supersaturated salts and their crystals. UMOD expression, biosynthesis and excretion are regulated in a complex manner, and dysregulation is found in a wide range of pathological conditions. It is strongly reduced or absent in cases with mutations in UMOD, renin, HNF1B and other genetic disorders causing autosomal dom-
\end{abstract}

inant hyperuricemic nephropathy. In contrast, elevated UMOD excretion may be associated with, and thus predictive of, chronic kidney disease. UMOD analysis is therefore of importance in all conditions with renal involvement and may be useful in the proper classification of renal diseases.

Copyright $\odot 2010$ S. Karger AG, Basel

\section{Introduction}

Uromodulin (UMOD) or Tamm-Horsfall protein (THP) is a protein selectively expressed by epithelial cells of the thick ascending limb of Henle's loop (TALH). Normally, the synthesized protein is cotranslationally translocated into the endoplasmic reticulum (ER), glycosylated, glypiated and secreted, and glycosylphosphatidylinositol (GPI) - anchored to the apical tubular cell membrane $[1-3]$. From this site the protein is released by a specific, but as yet unidentified, protease [4-6]. The released protein is excreted in the urine and represents the most abundant urinary protein in the healthy individual [7]. In the urine, the protein precipitates and is the main constituent of hyaline urinary casts [8-10].

UMOD expression and localization in kidney and its urinary excretion have been extensively studied in various pathophysiological states, and altogether more than 1,000 UMOD-related studies have been published. Unfortu-

\section{KARGER \\ Fax +41613061234 \\ E-Mail karger@karger.ch}

www.karger.com
() 2010 S. Karger AG, Basel

1420-4096/10/0336-0456\$26.00/0

Accessible online at:

www.karger.com/kbr
Stan Kmoch, PhD

Institute for Inherited Metabolic Disorders

Ke Karlovu 2, CZ-128 00 Prague 2 (Czech Republic)

Tel. +420 224967 691, Fax +420 224920293

E-Mail skmoch@lf1.cuni.cz 
nately, most of these studies used nonstandardized analytical methods for UMOD determination, resulting in a group of investigations which provide quite conflicting results and ambiguous conclusions. As a result, the exact biological roles of UMOD remain unclear and there has been a gradual decline of research interest in this protein.

The interest in UMOD biology and function was revived recently by the seminal work of Hart et al. [11] who identified causative $U M O D$ mutations in a subset of families suffering from familial juvenile hyperuricemic nephropathy (FJHN) and medullary cystic kidney disease type 2 (MCKD2) [12]. Further stimuli have been undoubtedly provided by recently identified associations of common UMOD variants with chronic kidney disease, reduced estimated glomerular filtration rate and urinary UMOD excretion [13, 14], and by novel proteomic approaches allowing detailed fingerprinting of renal diseases [15-22].

The aim of this review is to provide an update on current knowledge (and guesses) of UMOD biology, function and pathophysiology, and to summarize the results of published studies reporting clinically relevant changes in UMOD expression and excretion.

\section{Discovery of UMOD by Igor Tamm and Frank Lappin Horsfall}

In 1950, Tamm and Horsfall [23] isolated a substance from human urine that acted as a potent in vitro inhibitor of virus-mediated hemagglutination. They determined its inhibitory and physicochemical properties and concluded that the substance was similar in structure to mucoproteins [24].

A number of chemical (elemental composition), biochemical (amino acid composition, carbohydrate content, supramolecular structure, molecular weight, pI and electrophoretic mobility), physicochemical (solubility, $\mathrm{pH}$ and thermal stability) and physical (viscosity, diffusion coefficient, ultraviolet and infrared absorption spectra, extinction coefficient, refractive index, and rheology) properties were determined in ongoing studies in the 1950s [25-30] and 1960s [31-40], and re-evaluated in the 1970s [41-45].

These studies showed that urinary THP has a molecular weight of $80-90 \mathrm{kDa}, 20-30 \%$ of which is derived from high sialic acid content $\mathrm{N}$-linked glycans. It contains a very high number of cysteine residues (48) that are completely engaged in disulfide bond formation. THP is the most abundant protein in normal urine, and is excreted at the average rate of $50 \mathrm{mg} /$ day. In low-salt solutions, it forms supramolecular filamentous aggregates of variable molecular weight ranging up to $7 \times 10^{6} \mathrm{kDa}$.

It is notable that these aggregates were directly visualized in several studies by electron microscopy $[28,31,41$, 46-48] and conditions and molecular mechanisms for their formation were established [46, 47, 49-52].

In the group of studies performed in parallel, THP was shown to be present in urine of other mammals [53-57].

In 1985, Muchmore and Decker [58] used lectin-based affinity chromatography to isolate a glycoprotein with in vitro immunosuppressive properties from the urine of pregnant women, and called the protein uromodulin. It underwent further independent characterizations [5963] until Pennica et al. [64] proved, by complementary DNA (cDNA) analysis, that UMOD and THP are identical proteins. The term uromodulin (UMOD) will be used henceforth in this paper.

\section{UMOD Gene}

$U M O D$ is located at cytogenetic band 16p12.3 according to major gene databases (Ensembl, UCSC, Entrez Gene, HGNC and GeneCards), except for the GeneAtlas database (http://genatlas.medecine.univ-paris5.fr), where it is located at $16 \mathrm{p} 13.11$. The physical position of UMOD is between 20,344,374-20,364,037 bp on chromosome 16 according to GRCh37/hg19 assembly. The gene is transcribed from the 'plus' strand (encoded on the 'minus' strand) into 2 major transcripts differing in their 5 ' untranslated region, but encoding the identical protein (http://www.ncbi.nlm.nih.gov/sites/entrez?db=gene).

$U M O D$ is transcribed exclusively in the kidney as shown by Northern blot analysis [64] and a number of tissue specific gene expression profiling studies (http:// biogps.gnf.org). The transcription specificity of $U M O D$ is determined by its promoter sequence. It was shown that 3, 3.9 and $1.5 \mathrm{kbp}$ of mouse [65], bovine [66] and goat [67] genomic sequences, respectively, located upstream of the first $U M O D$ exon lead to kidney-specific expression of reporter genes in transgenic animals. The same was shown for $5.6 \mathrm{kbp}$ of human genomic sequence, consisting of 3.7 $\mathrm{kbp}$ promoter, exon 1, intron 1 and the untranslated part of exon 2 [68]. $5^{\prime}$ stepwise deletions of the bovine UMOD promoter revealed cis elements critical to transcription specificity are located within the first $600 \mathrm{bp}$ adjacent to the transcription initiation site [66]. Zhu et al. [65] identified the first $589 \mathrm{bp}$ of the UMOD promoter as being highly conserved in humans, rats, mice and cows. 


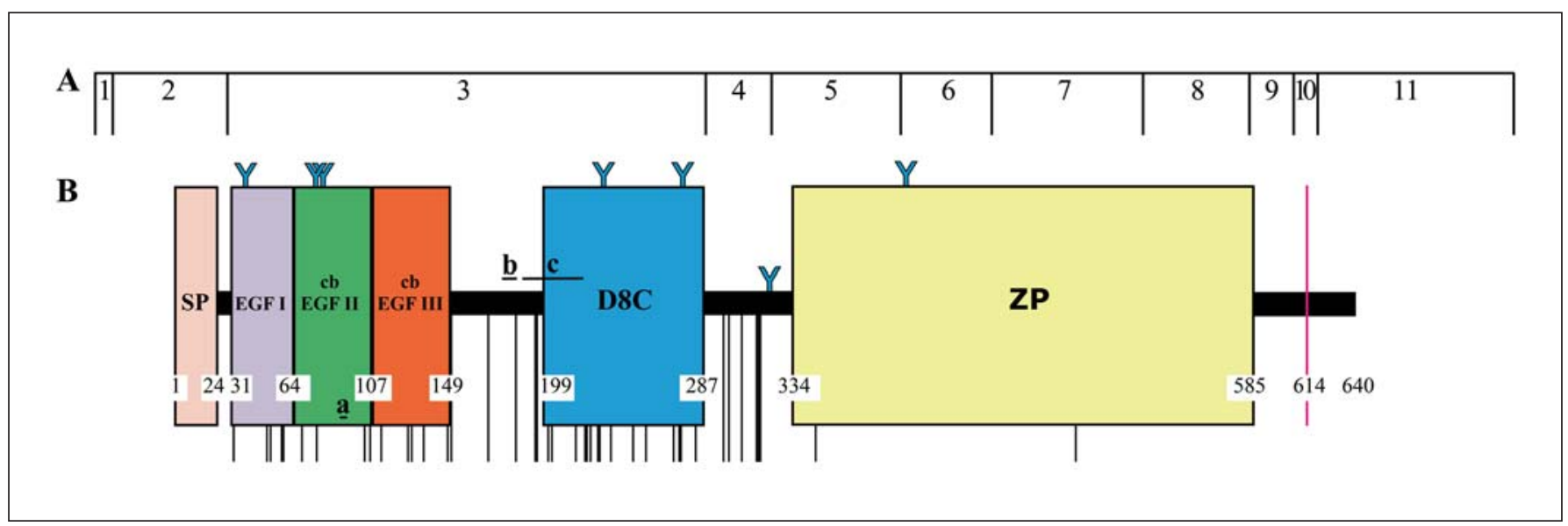

Fig. 1. Schematic representation of uromodulin $\mathrm{mRNA}$ and protein. A Representation of UMOD mRNA with exons 1-11 in their actual proportions. B Scheme of UMOD precursor depicted as domains (vertical color boxes) on the protein backbone (horizontal thick black box) in their actual proportions. The domains' starts and ends are shown on their lower halves. The GPI attachment site is indicated by vertical magenta line at position 614. Missense mutations are indicated by vertical black lines in their actual sites. Deletions in their actual ranges are indicated by horizontal black lines accompanied by letters: a (p.V93_G97del/insAASC), $\underline{\mathbf{b}}$ (p.H177_R185del) and $\underline{\mathbf{c}}$ (p.E188_L221del). Y = Potential N-glycosylation site; $\mathrm{SP}=$ signal peptide; $\mathrm{EGF}=$ epidermal growth factor-like; cbEGF = calcium-binding epidermal growth factor-like; $\mathrm{D} 8 \mathrm{C}=8$-cysteine domain; $\mathrm{ZP}=$ zona pellucida. (Adapted and revised from M. Živná(C, PhD Thesis, 2010).

proceed through the secretory pathway. During biosynthesis, the UMOD precursor is cotranslationally translocated into the ER. There the signal peptide is cleaved, and the protein is glycosylated on 7 of its 8 potential N-glycosylation sites [1,75], disulfide bridges are formed and glypiation on its C-terminus (probably on S614) occurs. N-glycan moieties are further trimmed in the Golgi apparatus.

Both mature glycan moieties and GPI modification act as sorting signals [76,77], routing the protein to the apical membrane of epithelial cells of the TALH, macula densa segment and distal convoluted tubule (DCT) as proven by immunohistochemistry $[3,70,78-81]$, immunofluorescence $[56,82-87]$ and immunoelectron microscopy [78, $85,88,89]$ analyses.

Here the protein is finally GPI-anchored [1] and, facing the tubular lumen, it forms supramolecular structures [46], thereby ensuring some of its proposed physiological functions.

From the luminal side of the membrane, the protein is actively released by a specific, but currently unidentified, protease $(\mathrm{s})[4,5]$. Proteolytic cleavage was originally proposed to occur after the residue F548 [5], but was later precisely assigned to the residue F587 [6]. This implies that urinary UMOD is composed of 563 amino acids and, depending on its glycosylation status, migrates as an $80-$ $90 \mathrm{kDa}$ band on SDS-PAGE. 
In addition to this classical apical targeting, to a minor degree UMOD also sorts to the basolateral pole of tubular epithelial cells as shown by sensitive immunomethods [3, $78,85,90]$. These observations are in line with the presence of UMOD in circulation [91] as proven by mass spectrometry analyses of the human plasma proteome (http:// www.peptideatlas.org, http://www.ebi.ac.uk/pride).

\section{Biochemical Analysis}

Isolation of UMOD is usually performed by classical salt-out precipitation of urine [23], with several modifications in postprecipitation steps. The resulting preparation can be further purified by gel filtration [92]. As a quicker, as well as low-cost, alternative to precipitation, a method employing diatomaceous earth as a filter material $[93,94]$ was developed and evaluated for clinical purposes [95].

Qualitative and semiquantitative analysis of UMOD in complex samples such as urine, cultured cell lysates and tissue homogenates is usually performed by SDS PAGE followed by detection with Coomassie brilliant blue staining, or by Western blotting and immunodetection $[70,80]$. These methods are easy to set up, inexpensive, easily scalable and informative. UMOD antibodies are commercially available from several vendors; therefore, they can be routinely used to examine urinary UMOD excretion as a 1st step in the diagnostic process for UMOD-associated kidney diseases (UAKD; our experience). Qualitative and quantitative UMOD analyses by mass spectrometry offer promising but technically more demanding approaches $[6,80,96]$.

Quantitative analysis of UMOD has been mostly performed by enzyme-linked immunosorbent assay (ELISA). Both indirect as well as direct ELISA setups have been reported for urinary $[5,97-101]$ and serum $[91,102$, 103] measurements. In the 1990s, Syn ${ }^{\text {elisa }}$ THP immunoassay was available from Elias Medizintechnik $\mathrm{GmbH}$ (Freiburg, Germany; which later became Elias/Pharmacia \& Upjohn), but its production was eventually discontinued. However, a new ELISA kit became available in 2009 from MD Biosciences GmbH (Zürich, Switzerland). Besides ELISA, radioimmunoassay [52, 92, 104-108], radial immunodiffusion $[109,110]$ and electroimmunoassay $[111,112]$ have also been used in the past. An elegant and highly quantitative immunomethod based on the Luminex platform has been described recently [14]. An analytical method based on high-performance liquid chromatography with native fluorescence detection [113] offers an alternative to immunoassay. Finally, SDS-PAGE and densitometry quantitation of bands after staining has been used as a fully quantitative approach in several studies [114-116].

In situ detection of UMOD in kidney tissue specimens and cultured cells is performed using standard immunohistochemical, immunofluorescence and immunoelectron microscopy methods [70, 71, 91, 98, 117-120]. Quantitative in situ analysis of UMOD may be performed by immunogold-electron microscopy with particle counting [117]. Quantitative assessment of the UMOD display on the surface of cultured cells is performed mainly by fluorescence-activated cell sorter analysis $[3,70,98,117]$, but ELISA can be also used for this purpose [3].

\section{UMOD Physiology}

GPI-anchoring, multidomain and supramolecular gellike structures on the luminal side of the plasma membrane of epithelial cells, together with rich and highly variable post-translational protein modification and a massive presence of the polymerized protein in urine, suggest that UMOD may have multiple and site-specific physiologic functions. However, despite 60 years of UMOD research, these physiological functions still remain rather elusive, and they have been mostly predicted from the protein primary structure, localization and in vitro experiments. Below we recapitulate those proposed functions in the context of some of our purely hypothetic, mechanistic ideas.

UMOD Function in Biogenesis and Organization of the Apical Membrane of TALH Cells

GPI anchor, N-linked glycosylation and a tendency towards polymerization are well-established factors in the sorting of apical membrane proteins [121]. Regarding its massive production, it can be assumed that UMOD biosynthesis may play, either directly or indirectly, an important role in the formation of apical membrane-targeted cargo vesicles and vesicular trafficking. GPI-anchored proteins also associate with lipid raft domains that play a role in the organization and dynamics of the apical membrane and in signal transduction [122]. A highly ordered organization of apical membranes allows for close packing of GPI-anchored proteins on the cell membrane. In the case of UMOD, this probably promotes formation of complex filamentous gel-like structures, providing the water barrier on the luminal plasma membrane of TALH cells and serving as a physical barrier to water permeability. Such a barrier may play an important role in ion transport and maintenance of countercurrent gradient in the interstitium $[78,123]$. 


\section{UMOD-Mediated Endocytosis}

Recent identification of GPI-enriched endocytic compartments $[124,125]$ have led to the hypothesis that UMOD may serve as a receptor for binding and endocytosis of yet to be defined ligands (cytokines, TNF, etc.). This may also play a role in modulation of cell surface events, receptor engagement and signal transduction along the corresponding nephron segment.

\section{UMOD as a Component of Primary Cilia}

Recently, it has also been shown that UMOD localizes to cilia [126], which suggests that it may contribute to mechanosensation of urinary flow, Wnt signaling, cell cycle regulation and planar cell polarity.

\section{Urinary UMOD Functions}

Following its protease-mediated shedding from the apical membrane of TALH cells, massive amounts of UMOD are released into the tubular fluid. One can imagine that the released protein maintains its gel-like and/or molecular sieve-like structures, interacting or associating with other UMOD molecules, which are still plasma membrane anchored. This structure may form a slowly moving polyanionic gel potentially serving several advantageous functions. It may contribute to the colloid osmotic pressure and retard passage of positively charged electrolytes (sodium and potassium) through the TALH and thus enhance their active transport and reabsorption in this segment.

Passing further along the distal tubule and collecting duct, this polyanionic phase-like structure may bind uropathogenic bacterial strains [127-129] and prevent their adherence to glycoproteins and glycolipids on luminal plasma membranes and, hence, urinary tract infections.

In this way, UMOD may also act as an inhibitor of urinary stone formation and adhesion [130-136], as well as a platform for the removal of proteins, cells and debris that are formed in the distal tubule.

Finally, not by direct binding as suggested [137], but through electrostatic (ionic) interaction, it may reduce uric acid transport in the distal tubule [138-140] and thus contribute to final tuning of uric acid excretion in kidney.

\section{Lessons from Knockout Mouse Models}

Some of the proposed physiological roles of UMOD were evaluated by the generation and examination of Umod $^{-/-}$mice models established by independent groups $[141,142]$. In both cases, it was shown that knockout (KO) mice suffered significantly more frequently from urinary tract infections. Indeed, Raffi at al. $[143,144]$ showed that
UMOD could act as a general host defense factor against urinary tract infections.

Mo et al. [145] showed that a portion of KO mice spontaneously formed calcium oxalate stones primarily in the collecting duct of the deep medulla and papilla. The rate of stone formation and crystal abundance were substantially increased in KO mice on a special stone formationinducing diet. Stone formation was never observed in wild-type littermates in either condition. Recently, it was also shown that these mice are more prone to ischemiainduced kidney injury than wild-type mice, and that the process was accompanied by altered tubular expression of Toll-like receptor 4 [146].

Although the examination of steady-state electrolyte handling showed no abnormalities in KO mice [147], creatinine clearance was significantly reduced. Impaired urine concentration ability was observed under water deprivation. Moreover, biochemical and histochemical quantitative approaches used to assess changes in the biosynthesis of proteins related to $\mathrm{NaCl}$ transport along the nephron revealed upregulation of major distal transporters and downregulation of juxtaglomerular apparatus components, consistent with the adaptation to altered $\mathrm{NaCl}$ reabsorption in the TALH.

The same authors further observed a significant difference in the ratio of urinary sodium concentrations and urinary urate concentrations between $\mathrm{KO}$ and wild-type mice [148] - KO mice excreted less uric acid for a given amount of sodium, a result consistent with previously observed dysregulation of $\mathrm{NaCl}$ transport-related proteins. Interestingly, mRNA levels of PT urate transporters were found to be normal, suggesting that the upregulation of their expression is not responsible for increased urate reabsorption. It is important, however, to remember that the transporters for urate are very different between mice and humans, and that mice normally produce and reabsorb only small amounts of urate [149].

\section{UMOD in Inflammation and Immunity}

A number of studies have suggested that UMOD plays a role in inflammation processes and modulation of immune system responses [3, 58-63, 150-159]. This notion, however, comes mostly from in vitro studies or in vivo studies performed under artificial conditions, and their relevance for physiology and particularly for pathophysiology is debatable. For this reason, this topic is not further discussed in this review. 


\section{UMOD Pathophysiology}

UMOD function(s), especially in humans, can be deduced to some extent from clinical and biochemical coincidences and/or consequences associated with changes in UMOD primary structure, transcription, expression, post-translational modification, localization and urinary excretion that have been identified and studied in a number of pathological states.

\section{UMOD Mutations}

$U M O D$ mutations have been identified in patients suffering from FJHN (OMIM 162000), MCKD2 (OMIM $603860)$ or glomerulocystic kidney disease (GCKD) (OMIM 609886) [11, 12, 70]. At this time, 58 different mutations in the UMOD gene have been reported in the literature $[11,12,70,71,73,96-98,117,119,126,160-168]$. Most of the mutations occur in exons 3 and 4 . Fifty-five are missense mutations and 3 are in-frame deletions leading to the loss of 5-33 amino acids (fig. 1). Interestingly, mutations reducing either $U M O D$ transcript amount or encoding for completely truncated protein have not yet been identified as a cause of UAKD.

The observed mutational spectrum implies a dominant-negative effect of the mutations. Indeed, identified mutations in $U M O D$ affect biosynthesis of the protein, which leads to its aberrant intracellular trafficking, ER storage, altered formation of supramolecular domains on the apical plasma membrane of TALH cells, abnormal UMOD expression in the kidney and decreased urinary UMOD excretion [70, 91, 96, 98, 117, 120, 160]. These events may initiate various physiologic reactions, such as ER stress and tubulointerstitial injury, and lead to progressive renal damage eventually requiring dialysis and renal transplantation. The hyperuricemia and reduced urinary concentration, biochemical hallmarks of FJHN/ MCKD, are likely related [72]. As described previously, UMOD is likely important in keeping the TALH watertight. Loss of the integrity of the TALH would decrease the concentrating ability of the loop of Henle and result in decreased urinary concentration. The decreased ability to reabsorb sodium in the thick ascending limb would be balanced by an increase in PT reabsorption of sodium and secondarily of uric acid, resulting in hyperuricemia.

\section{Uromodulin-Associated Kidney Diseases}

Initial linkage mapping studies have shown that FJHN/MCKD is genetically heterogeneous [163, 169172]. Following the discovery of UMOD mutations, subsequent sequencing studies revealed that $U M O D$ muta- tions are present in at most $30 \%$ of families presenting with symptoms fulfilling diagnostic criteria of FJHN/ MCKD, i.e. autosomal dominant inheritance of hyperuricemia resulting from decreased fractional excretion of urate, impaired urine concentration ability, attacks of gouty arthritis and progressive renal insufficiency associated with early onset, nonspecific tubulointerstitial lesions, hypertension and inconstantly with renal corticomedullary cysts.

While the term 'uromodulin-associated kidney disease' was first proposed by Hart et al. in 2002 [11] to describe families with mutations in the UMOD gene, we believe that UMOD abnormalities are an important component of the pathophysiology in other individuals with the clinical syndrome of autosomal dominant hyperuricemia and kidney disease.

In our research $[98,173,174]$, we have shown that altered UMOD biology may account for this clinical syndrome in many individuals, despite different underlying genetic defects. We performed qualitative and quantitative analysis of urinary UMOD excretion in 12 and 15 families, respectively. Both Western blot and ELISA revealed significantly decreased urinary UMOD excretion in all but one of the families examined. In addition, we performed immunohistochemical analysis of UMOD and epithelial membrane antigen mucin (MUC1), the protein transported through the same secretory pathway as UMOD, in kidney sections representing putatively 4 different genetic defects leading to UAKD.

In individuals with $U M O D$ mutations, urinary UMOD is usually normal during childhood (despite hyperuricemia being present) [164; Vyletal, unpublished data], and its excretion gradually reduces to total absence. The gradual decrease reflects a process of massive intracellular accumulation of UMOD in tubular cells, leading to tubulointerstitial injury probably facilitated by ER stress.

We also identified reduced urinary UMOD excretion resulting from attenuated $U M O D$ expression in families presenting with anemia and hyperuricemia caused by mutations in the renin signal sequence $[98,174]$ (Bleyer et al., unpubl. data).

Similarly, we observed reduced UMOD excretion and expression patterns in a family with features of FJHN associated with diabetes mellitus, in which a mutation in the HNF1B gene on chromosome 17q12 was found [175]. HNF1B is a critical regulator of $U M O D$ transcription [176], so it may be expected that similar UMOD profiles will be present in many sporadic and/or familial cases with renal disease resulting from $H N F 1 B$ mutations [177]. 
We also observed reduced urinary UMOD excretion in a group of patients with none of the genetic defects described above. A mong them, the reduced urinary UMOD excretion reflected either low intracellular UMOD positivity associated with strong presence of UMOD in the hyaline casts or cases with irregular, mosaic-like UMOD staining patterns. Interestingly, in all these cases the UMOD staining patterns were mostly correlated with those of apical membrane marker MUC1 [98], suggesting a general secretory defect.

\section{Mouse Models with UMOD Mutations}

To recapitulate the FJHN/MCKD phenotype and to get a tool for studying etiopathogenesis of UAKD, several mouse strains with Umod point mutations have been recently generated.

Takiue et al. $[178,179]$ generated transgenic mice using a chimeric transgene composed of mouse Umod promoter and human UMOD cDNA harboring mutation c.444T $>\mathrm{G}$ (p.C148W). Nevertheless, these mice did not develop any UAKD symptoms except for the cytoplasmic accumulation of UMOD in TALH and DCT epithelial cells. However, accumulated protein was not the product of the transgene, but rather of endogenous wild-type Umod.

Kemter et al. [180] reported $N$-ethyl- $N$-nitrosourea (ENU)-induced mutant mice harboring mutation c.871G $>$ A (p.A227T), which has not yet been found in humans and is predicted as tolerated by SIFT analysis (http://sift.jcvi.org/). These mice developed some of the features of UAKD, but in a homozygous rather than heterozygous state. Moreover, the mutant animals developed additional urea and bone metabolism alterations never observed in human UAKD patients.

Eventually, in 2010 Bernascone et al. [181] generated a mouse harboring Umod mutation c.441T>G (p.C147W), analogous to the well-studied human $U M O D$ mutation c444T $>$ G (p.C148W). They used a transgene of exclusively murine origin. Transgenic mice recapitulated most of the biochemical (except for hyperuricemia, most probably due to expression of uricase in mice), clinical and histological features of UAKD in humans, including reduced urinary concentration ability, renal insufficiency with increased serum creatinine concentrations, renal cysts, progressive tubulointerstitial injury and accumulation of mutant UMOD in ER of TALH and DCT epithelial cells.

\section{UMOD Expression}

There is a great amount of $U M O D$ expression data deposited in gene expression databases (www.nextbio.com, www.ncbi.nlm.nih.gov/geo) that come from microarraybased studies focused on various renal pathologies. For example, decreased $U M O D$ expression was detected in end-stage renal disease [182] and in cysts from autosomal dominant polycystic kidney disease type 1 patients [183]. It has been shown that UMOD expression is decreased in all kidney neoplasms studied so far - benign as well as malignant (https://expo.intgen.org/geo) [182, 184-195], chronic renal transplant rejections of grades II grade III $[196,197]$, interstitial fibrosis after renal transplantation [198] and renal grafts with delayed function (gse10419). $U M O D$ gene expression was increased, however, in diabetic nephropathic glomeruli [199].

\section{Urinary UMOD Excretion}

Several studies $[107,130,200,201]$ attempted to evaluate factors determining physiological UMOD excretion, but provided conflicting results. During the day, there is considerable variation in excretion in adults, but it apparently correlates with urinary volume in individuals in antidiuresis and in those drinking in response to thirst [107]. A positive correlation of the excretion with dietary intake of salt was indicated in humans [200] as well as rats [202].

UMOD excretion seems to increase gradually from birth to adulthood [203-206], where it remains stable until a decline after 60 years of age $[207,208]$. The urinary $\mathrm{UMOD} /$ creatinine ratio seems to be relatively stable from 4 years of age through the 7 th decade of life $[97,204]$.

UMOD half-life turnover was estimated to be $16 \mathrm{~h}$ in humans [209], but ranges as wide as 3-7 to $168 \mathrm{~h}$ have been proposed [107].

It was also shown that urinary excretion is correlated with (estimated) glomerular filtration rate [201, 204, 210] and hence corresponds to declining kidney function in virtually all chronic kidney diseases.

Numerousstudiesconducted mainlyin the 1980s/1990s attempted to correlate urinary UMOD excretion with various clinical conditions. In these studies, UMOD was quantified in urine samples mainly by different ELISA, radioimmunoassay or electroimmunoassay analyses. Table 1 presents a comprehensive overview of urinary UMOD excretion in various pathological conditions. As can be seen, major attention was given to diabetes and nephrolithiasis.

In diabetes type I, it was shown that decreased UMOD excretion is predictive of renal failure and cardiovascular disease in adults [211]. In affected children, however, other tubular markers seem to be more informative [212]. In nephrolithiasis, results from different studies 
Table 1. Urinary UMOD excretion in various pathological conditions

\begin{tabular}{|c|c|c|c|}
\hline Condition & Method & Trend & Ref. \\
\hline \multicolumn{4}{|l|}{ Acute renal failure } \\
\hline Oliguric phase & \multirow[t]{2}{*}{ RIA } & $\downarrow$ & \multirow[t]{2}{*}{221} \\
\hline Polyuric phase & & $\uparrow$ & \\
\hline Asthma & RIA & $\uparrow$ & 222 \\
\hline \multirow[t]{4}{*}{ Balkan endemic nephropathy } & EIA & $\uparrow($ all groups) & 223 \\
\hline & EIA & $\uparrow($ all groups) & 200 \\
\hline & SDS-PAGE+D & 0 & 224 \\
\hline & EIA & $\uparrow$ (at risk) & 225 \\
\hline Tubular proteinuria & EIA & $\uparrow$ & 226 \\
\hline \multicolumn{4}{|l|}{ Burns } \\
\hline Moderate to severe & \multirow[t]{2}{*}{ RIA } & $\uparrow$ & \multirow[t]{2}{*}{227} \\
\hline Very large or renal failure & & $\downarrow$ & \\
\hline \multirow[t]{2}{*}{ Cadmium nephropathy } & RIA & $\uparrow$ & 228 \\
\hline & $\mathrm{SSA} / \mathrm{CBBC}^{\dagger}$ & $\uparrow$ & 229 \\
\hline \multicolumn{4}{|l|}{ Chemotherapy } \\
\hline \multirow[t]{2}{*}{ Cisplatin } & ELISAh & $\uparrow$ & 230 \\
\hline & ELISAh & $\uparrow$ & 231 \\
\hline Ifosfamide & SDS-PAGE+D & $\downarrow(60 \%)$ & 232 \\
\hline Cyclosporin A & RIA & $\downarrow$ & 233 \\
\hline \multirow[t]{2}{*}{ Chronic nephropathy } & RIA & $\downarrow$ & 201 \\
\hline & ELISAh & $\downarrow(78 \%)$ & 210 \\
\hline Glomerulonephritis & ELISAh & $\downarrow$ & 234 \\
\hline Diabetic nephropathy & & $\downarrow$ & \\
\hline PKD & & $\downarrow$ & \\
\hline Tubulointerstitial nephropathy & & $\downarrow$ & \\
\hline Chronic renal failure & EIA & $\downarrow$ & 112 \\
\hline \multicolumn{4}{|l|}{ Diabetes (type I) } \\
\hline \multirow[t]{2}{*}{ Children $4-15$ years } & ELISAh & $\downarrow(25 \%)$ & 235 \\
\hline & ELISAh & 0 & 212 \\
\hline Children during ketoacidosis & ELISAh & $\downarrow$ & 236 \\
\hline Renal failure and cardiovascular death & ELISAh & $\downarrow$ & 211 \\
\hline Retinopathy & ELISAh & 0 & 237 \\
\hline \multirow[t]{3}{*}{ Diabetic nephropathy } & ELISAh & $\downarrow$ & 238 \\
\hline & ELISAh & $\downarrow$ & 239 \\
\hline & RIA & $\downarrow$ & 108 \\
\hline+ macroalbuminuria & ELISAh & $\downarrow$ & 240 \\
\hline \multirow[t]{2}{*}{ +microalbuminuria } & ELISAh & 0 & 241 \\
\hline & & 0 & 230 \\
\hline w/o nephropathy & & 0 & 238 \\
\hline +microalbuminuria & ELISAh & 0 & 242 \\
\hline w/o any complications & & $\downarrow$ & 239 \\
\hline \multirow[t]{4}{*}{ Normotensive, normoalbuminuria } & ELISAh & $\uparrow(\mathrm{DM}>10$ years $)$ & 99 \\
\hline & & $\downarrow(\mathrm{DM}>15$ years $)$ & \\
\hline & ELISAh & $0(\mathrm{DM}<9$ years; $>15$ years $)$ & 243 \\
\hline & & $\uparrow($ DM $10-14$ years $)$ & \\
\hline Overnight & ELISAh & 0 & 244 \\
\hline Orthostasis & & 0 & \\
\hline Acute euglycemia + water load & & $\uparrow$ & \\
\hline Women (postmenopausal) & ELISAh & $\downarrow$ & 245 \\
\hline \multicolumn{4}{|l|}{ Diabetes (type II) } \\
\hline Women (postmenopausal) & & 0 & 245 \\
\hline Renal failure and cardiovascular death & & 0 & 211 \\
\hline Diabetes (nonselected) & LIA & $\downarrow$ & 246 \\
\hline
\end{tabular}


Table 1 (continued)

\begin{tabular}{|c|c|c|c|}
\hline Condition & Method & Trend & Ref. \\
\hline Elderly & ELISAh & $\downarrow$ & 208 \\
\hline Women (disaggregated) & ELISAh & $\downarrow$ & 247 \\
\hline Women (aggregated) & & $\uparrow$ & \\
\hline Normotension & RIA & $\downarrow$ & 207 \\
\hline \multicolumn{4}{|l|}{ Fanconi syndrome } \\
\hline Cystinosis & \multirow{5}{*}{$\begin{array}{l}\text { 1-DE, 2-DE+MS } \\
\text { 2-DE+MS }\end{array}$} & $\uparrow$ & 228 \\
\hline \multirow[t]{2}{*}{ Dent's disease } & & $\downarrow$ & 248 \\
\hline & & $\downarrow$ & 249 \\
\hline Lowe's disease & & $\downarrow$ & \\
\hline AD idiopathic & & $\downarrow$ & \\
\hline Hyperprostaglandin E-syndrome & ELISAh & $\downarrow$ & 250 \\
\hline \multicolumn{4}{|l|}{ Hypertension } \\
\hline \multirow[t]{2}{*}{ Essential } & \multirow{3}{*}{ RIA } & 0 & 238 \\
\hline & & 0 & 251 \\
\hline Elders & & 0 & 207 \\
\hline \multirow[t]{2}{*}{ Interstitial cystitis } & ELISAh & $\uparrow$ & 252 \\
\hline & 2-DE+MS & $\downarrow$ & 253 \\
\hline \multicolumn{4}{|l|}{ Intravenous urography } \\
\hline Total & RIA & 0 & 254 \\
\hline Aggregated & & $\downarrow$ & \\
\hline \multirow[t]{2}{*}{ Lead exposure } & ELISAc & 0 & 255 \\
\hline & LIA & $\uparrow(30 \%)$ & 256 \\
\hline \multicolumn{4}{|l|}{ Lithiasis } \\
\hline \multirow[t]{7}{*}{ Nonselected } & SDS-PAGE(+WB)+D & $\downarrow$ & 257 \\
\hline & ELISAc & $\downarrow$ & 130 \\
\hline & & 0 & 201 \\
\hline & $\mathrm{SP}+\mathrm{F}-\mathrm{C}+\mathrm{Ph}$ & 0 & 258 \\
\hline & SDS-PAGE+D & $\downarrow$ & 115 \\
\hline & ELISAh & $\downarrow$ & 218 \\
\hline & RIA & $\uparrow$ & 259 \\
\hline Children & EIA & $\uparrow$ & 260 \\
\hline First time & SDS-PAGE+D & $\downarrow$ & 261 \\
\hline Recurrent & & 0 & \\
\hline \multirow[t]{6}{*}{$\mathrm{Ca}$} & $\mathrm{FE}+\mathrm{Sch}+\mathrm{P}$ & $\uparrow$ & 262 \\
\hline & & 0 & 112 \\
\hline & ELISAc & $\downarrow$ & 263 \\
\hline & ELISAc & 0 & 264 \\
\hline & EIA & 0 & 87 \\
\hline & EIA & 0 & 111 \\
\hline Idiopathic & $\mathrm{CTAB} /$ Asbestos $-\mathrm{BaBr}_{2}+\mathrm{HL}+\mathrm{Ph}$ & $\downarrow$ & 265 \\
\hline Children & EIA & 0 & 266 \\
\hline Potential formers (boys) & RID & 0 & 267 \\
\hline \multirow[t]{2}{*}{ +renal tubular acidosis } & EIA & $\downarrow$ & 268 \\
\hline & & $\downarrow$ & 87 \\
\hline \multirow[t]{2}{*}{ Recurrent } & SDS-PAGE+D & 0 & 116 \\
\hline & ELISAh & $\downarrow$ & 269 \\
\hline Familial & ELISAc & $\uparrow$ & 270 \\
\hline Idiopathic & RID & $\downarrow$ & 109 \\
\hline +acute UTI & & $\uparrow$ & 116 \\
\hline \multirow[t]{4}{*}{ Urate } & ELISAc & $\downarrow$ & 271 \\
\hline & & $\downarrow$ & 87 \\
\hline & & $\downarrow$ & 111 \\
\hline & & $\downarrow$ & 130 \\
\hline Cystine & & 0 & 87 \\
\hline Staghorn calculi & & $\downarrow$ & 111 \\
\hline
\end{tabular}


Table 1 (continued)

\begin{tabular}{|c|c|c|c|}
\hline Condition & Method & Trend & Ref. \\
\hline Lupus nephritis & ELISAh & $\downarrow$ & 272 \\
\hline Mercury vapors exposure & LIA & $\uparrow$ & 273 \\
\hline Nephrotic syndrome & $\mathrm{SP}+\mathrm{F}-\mathrm{C}+\mathrm{Ph}$ & $\uparrow$ & 205 \\
\hline $\begin{array}{l}\text { Newborns (1st week) } \\
\text { Prematurity (uncomplicated) } \\
\text { Asphyxiation } \\
\text { Respiratory distress syndrome (idiopathic) }\end{array}$ & RID & $\begin{array}{l}0 \\
0 \\
0\end{array}$ & 274 \\
\hline $\begin{array}{l}\text { Organic solvents exposure } \\
\text { Various } \\
\text { Dinitrotoluene } \\
\text { Perchloroethylene } \\
\end{array}$ & $\begin{array}{l}\text { NA } \\
\text { SDS-PAGE+D } \\
\text { LIA }\end{array}$ & $\begin{array}{l}0 \\
\uparrow(36 \%) \\
\uparrow\end{array}$ & $\begin{array}{l}275 \\
276 \\
277\end{array}$ \\
\hline Polycystic ovary syndrome & $\mathrm{SP}+\mathrm{TM}$ & $\downarrow$ & 278 \\
\hline $\begin{array}{l}\text { Pregnancy } \\
+ \text { Hypertension } \\
\text { Postpartum }\end{array}$ & $\begin{array}{l}\text { ELISAh } \\
\text { SDS-PAGE+D }\end{array}$ & $\begin{array}{l}\uparrow \\
0 \\
\downarrow \\
\downarrow(83 \%) \\
\uparrow(\text { transiently) } \\
0(92 \%)\end{array}$ & $\begin{array}{l}279 \\
280\end{array}$ \\
\hline Proximal renal cyst (simple) & RIA & $\uparrow$ & 281 \\
\hline Renal disease (various) & $\begin{array}{l}\text { RIA } \\
\text { EIA } \\
\text { SDS-PAGE+D }\end{array}$ & $\begin{array}{l}\downarrow \\
\downarrow \\
\downarrow \\
\downarrow\end{array}$ & $\begin{array}{l}282 \\
283 \\
284 \\
201\end{array}$ \\
\hline $\begin{array}{l}\text { Surgery } \\
\text { Children 3-13 years } \\
\text { Acute kidney failure postoperation } \\
\text { CPB }\end{array}$ & $\begin{array}{l}\text { ELISAh } \\
\text { ELISAc }\end{array}$ & $\begin{array}{l}0 \\
\downarrow\end{array}$ & $\begin{array}{l}285 \\
286\end{array}$ \\
\hline $\begin{array}{l}\mathrm{w} \text { and w/o AKI postoperation } \\
\mathrm{w} \text { renal dysfunction postoperation } \\
\text { w/o renal dysfunction postoperation } \\
\text { Elders } \\
\text { Stomach carcinoma post operation } \\
\text { Esophagus carcinoma post operation }\end{array}$ & $\begin{array}{l}\text { 2D-DIGE } \\
\text { ELISAc } \\
\text { ELISAc } \\
\text { SDS-PAGE+D }\end{array}$ & $\begin{array}{l}\downarrow \\
\downarrow \\
0 \\
0 \\
\downarrow \\
\downarrow\end{array}$ & $\begin{array}{l}287 \\
288 \\
289 \\
114\end{array}$ \\
\hline Transplantation & & & \\
\hline $\begin{array}{l}\text { Kidney (recipients) } \\
\text { Acute allograft rejection (4-14 days prior to) } \\
\text { Graft failure (acute tubular necrosis) } \\
\text { Graft failure (acute immune rejection) }\end{array}$ & $\begin{array}{l}\text { ELISAh } \\
\text { ELISAc } \\
\text { SP+F-C+Ph } \\
\text { ELISAh }\end{array}$ & $\begin{array}{l}0 \\
0 \\
\uparrow(\text { transiently) } \\
\downarrow \\
0\end{array}$ & $\begin{array}{l}290 \\
291 \\
206 \\
292\end{array}$ \\
\hline $\begin{array}{l}\text { Kidney (donors) } \\
\text { Bone marrow (pretransplant conditioning regimen) }\end{array}$ & $\begin{array}{l}\text { ELISAh } \\
\text { ELISAc } \\
\text { RIA }\end{array}$ & $\begin{array}{l}\uparrow \\
0 \\
0 / \uparrow(\text { during) }\end{array}$ & $\begin{array}{l}290 \\
293 \\
294\end{array}$ \\
\hline $\begin{array}{l}\text { Hematological stem cells } \\
\text { Liver (preoperation) }\end{array}$ & ELISAc & 0 & 295 \\
\hline $\begin{array}{l}\text { w renal insufficiency post operation } \\
\text { w/o renal insufficiency post operation }\end{array}$ & ELISAh & $\begin{array}{l}\downarrow \\
0\end{array}$ & 296 \\
\hline
\end{tabular}


Table 1 (continued)

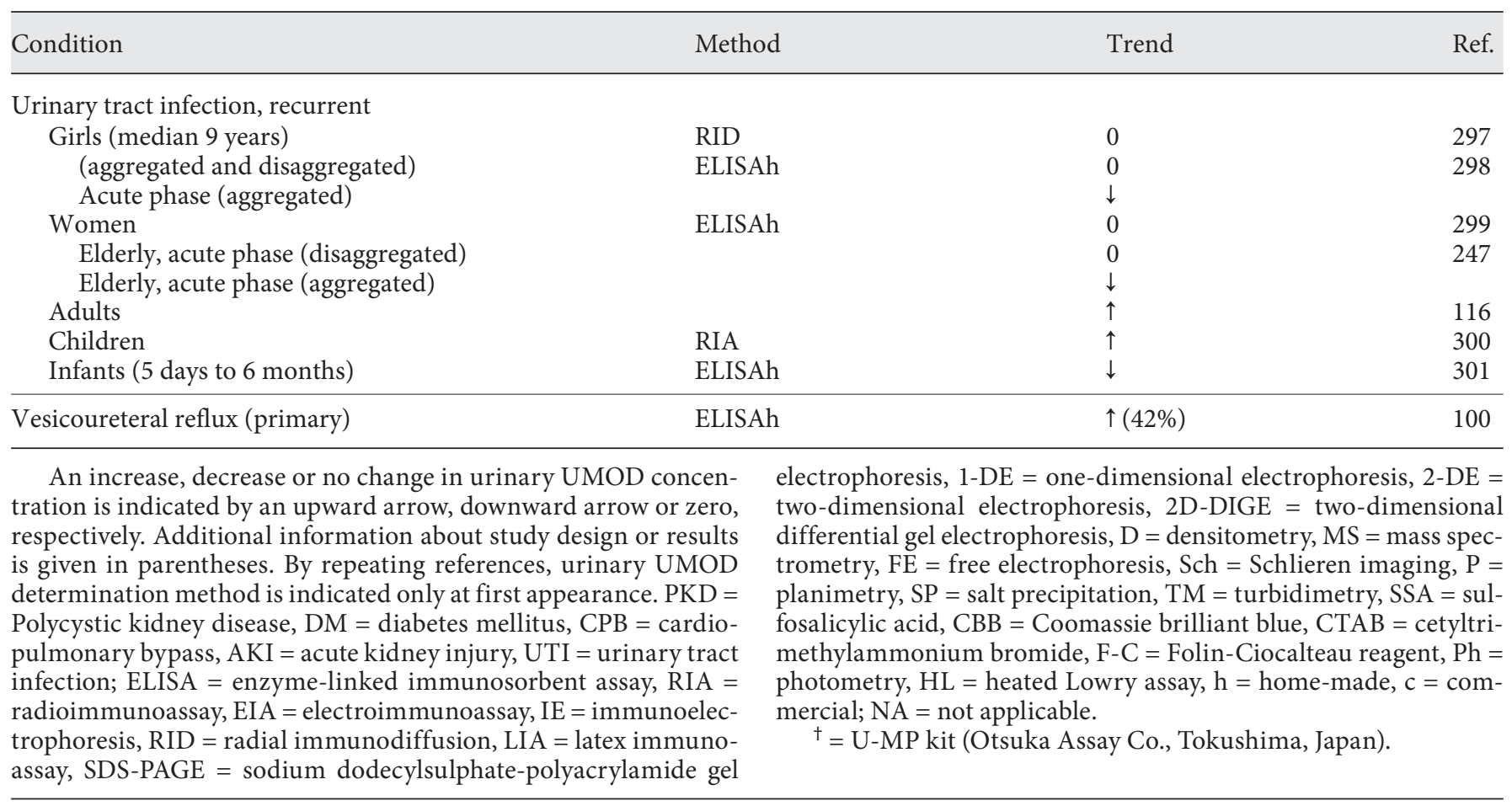

are contradictory and, hence, inconclusive. The UMOD excretion rate itself is not sufficient to predict and/or to explain susceptibility to crystal formation (see also next section).

Recently, we reported the results of UMOD urinary excretion in Fabry disease [80]. Interestingly, in about half of the examined hemizygous patients, we observed abnormal UMOD excretion patterns on Western blots, i.e. the presence of shorter aberrant protein forms. Subsequently, we observed identical patterns in several other thesaurismoses, namely mucolipidosis type II, GM1 gangliosidosis, metachromaticleukodystrophy and Schindler disease (Vyletal, unpubl. data).

\section{Subjects and Perspectives of Further Research}

UMOD has been known since 1950. Despite this, there are many questions for which satisfactory answers are still missing. In the past, interest in this remarkable molecule waxed and waned. We believe that we are currently experiencing a UMOD research renaissance due to its wellestablished role in UAKD, association of common UMOD variants with chronic kidney disease [13, 14, 213-215] and the availability of sensitive and quantitative urinary proteome analysis techniques [15-17, 19-22, 216, 217].

In UAKD, the pathogenetic mechanisms of aberrant UMOD trafficking must be better defined by studying responses and consequences of ER stress, apoptotic and ER-associated protein degradation (ERAD) pathways before any specific therapeutic targets may be devised.

Regarding continous massive UMOD biosynthesis, it can be assumed that even subtle changes in UMOD transcription, expression and intracellular trafficking may affect secretory pathway efficiency, membrane organization and, thus, UMOD expressing cell functionality. In this context, true biological consequences of identified common $U M O D$ variants must be studied through in silico and in vitro analysis of the $U M O D$ promoter and further assessed in relevant cellular and/or transgenic animal models.

There is still no consensus on the role of UMOD in nephrolithiasis. While some authors believe that it acts only as an inhibitor of aggregation and growth of calcium oxalate crystals, others state that it can function as an inhibitor or promoter, depending on a number of physicochemical properties of urine and (secondarily) on the activity of tubular cells [218-220]. 
Finally, as it has emerged that UMOD urinary excretion is altered, either primarily or secondarily, in numerous disease conditions, qualitative and quantitative UMOD analysis using urinary proteome analysis techniques deserves attention in all clinical states in which apparent or potential renal involvement comes into question.

\section{Conclusion}

UMOD is a protein expressed solely in the mammalian kidney, namely in TALH and early DCT epithelial cells in humans. It is extensively glycosylated, glypiated and GPI-anchored in the luminal side of the apical plasma membrane. Here, UMOD forms organized structures, probably ensuring water impermeability and countercurrent gradient. Besides this, it might contribute to various biological processes such as receptor-mediated endocytosis, mechanosensation of urinary flow, Wnt signaling, cell cycle regulation and planar cell polarity.

A specific, but as yet unidentified, protease(s) cleaves off and releases UMOD into urine, where it can be found in the highest concentrations compared to other urinary proteins. In urine, UMOD might contribute to the colloid osmotic pressure, retard passage of positively charged electrolytes and prevent a number of bacteria strains from attaching to tubular and bladder epithelia, therefore helping to prevent urinary tract infections. It modulates aggregation and growth of supersaturated salts and their crystals, respectively.

Urinary excretion of UMOD related to urinary creatinine is stable from 4 years of age in humans. UMOD gene expression, biosynthesis and excretion are regulated in a complex manner and reflect a wide range of pathological conditions.

UMOD excretion is strongly reduced or absent in cases with mutations in UMOD, REN and HNF1B genes, as well as other genetic disorders causing autosomal dominant hyperuricemic nephropathy (UAKD). In contrast, elevated UMOD excretion may be associated and, thus, predictive of chronic kidney disease.

Qualitative and quantitative analysis of UMOD urinary excretion is therefore important in all conditions with renal involvement and may be useful in the proper classification of renal disease based on analyses of urinary proteome.

\section{Acknowledgements}

This work was supported by institutional grants provided by the Ministry of Education of the Czech Republic (Projects MSM0021620806 and 1M6837805002) and by Grant 44309 provided by the Grant Agency of Charles University.

\section{References}

- 1 Rindler MJ, Naik SS, Li N, Hoops TC, Peraldi MN: Uromodulin (Tamm-Horsfall glycoprotein/uromucoid) is a phosphatidylinositol-linked membrane protein. J Biol Chem 1990;265:20784-20789.

-2 Serafini-Cessi F, Malagolini N, Hoops TC, Rindler MJ: Biosynthesis and oligosaccharide processing of human Tamm-Horsfall glycoprotein permanently expressed in HeLa cells. Biochem Biophys Res Commun 1993;194:784-790.

- 3 Kreft B, Jabs WJ, Laskay T, Klinger M, Solbach W, Kumar S, van Zandbergen G: Polarized expression of Tamm-Horsfall protein by renal tubular epithelial cells activates human granulocytes. Infect Immun 2002;70:26502656.

4 Cavallone D, Malagolini N, Serafini-Cessi F: Mechanism of release of urinary TammHorsfall glycoprotein from the kidney GPIanchored counterpart. Biochem Biophys Res Commun 2001;280:110-114.
5 Fukuoka S, Kobayashi K: Analysis of the C-terminal structure of urinary TammHorsfall protein reveals that the release of the glycosyl phosphatidylinositol-anchored counterpart from the kidney occurs by phenylalanine-specific proteolysis. Biochem Biophys Res Commun 2001;289: 1044-1048.

-6 Santambrogio S, Cattaneo A, Bernascone I, Schwend T, Jovine L, Bachi A, Rampoldi L: Urinary uromodulin carries an intact ZP domain generated by a conserved C-terminal proteolytic cleavage. Biochem Biophys Res Commun 2008;370:410-413.

7 Kumar S, Muchmore A: Tamm-Horsfall protein - uromodulin (1950-1990). Kidney Int 1990;37:1395-1401.

8 Cohen AH: Morphology of renal tubular hyaline casts. Lab Invest 1981;44:280-287.

$\checkmark 9$ Wenk RE, Bhagavan BS, Rudert J: TammHorsfall uromucoprotein and the pathogenesis of casts, reflux nephropathy, and nephritides. Pathobiol Annu 1981;11:229-257.
10 Fairley JK, Owen JE, Birch DF: Protein composition of urinary casts from healthy subjects and patients with glomerulonephritis. Br Med J (Clin Res Ed) 1983;287:1838-1840.

11 Hart TC, Gorry MC, Hart PS, Woodard AS, Shihabi Z, Sandhu J, Shirts B, Xu L, Zhu H, Barmada MM, Bleyer AJ: Mutations of the UMOD gene are responsible for medullary cystic kidney disease 2 and familial juvenile hyperuricaemic nephropathy. J Med Genet 2002;39:882-892.

12 Turner JJ, Stacey JM, Harding B, Kotanko P, Lhotta K, Puig JG, Roberts I, Torres RJ, Thakker RV: UROMODULIN mutations cause familial juvenile hyperuricemic nephropathy. J Clin Endocrinol Metab 2003;88: 1398-1401 
13 Kottgen A, Glazer NL, Dehghan A, Hwang S-J, Katz R, Li M, Yang Q, Gudnason V, Launer LJ, Harris TB, Smith AV, Arking DE, Astor BC, Boerwinkle E, Ehret GB, Ruczinski I, Scharpf RB, Ida Chen Y-D, de Boer IH, Haritunians T, Lumley T, Sarnak M, Siscovick D, Benjamin EJ, Levy D, Upadhyay A, Aulchenko YS, Hofman A, Rivadeneira F, Uitterlinden AG, van Duijn CM, Chasman DI, Pare G, Ridker PM, Kao WHL, Witteman JC, Coresh J, Shlipak MG, Fox CS: Multiple loci associated with indices of renal function and chronic kidney disease. Nat Genet 2009;41:712-717.

14 Kottgen A, Hwang SJ, Larson MG, Van Eyk JE, Fu Q, Benjamin EJ, Dehghan A, Glazer NL, Kao WH, Harris TB, Gudnason V, Shlipak MG, Yang Q, Coresh J, Levy D, Fox CS: Uromodulin levels associate with a common UMOD variant and risk for incident CKD. J Am Soc Nephrol 2010;21:337-344.

-15 Drube J, Schiffer E, Mischak H, Kemper MJ, Neuhaus T, Pape L, Lichtinghagen R, Ehrich $\mathrm{JH}$ : Urinary proteome pattern in children with renal Fanconi syndrome. Nephrol Dial Transplant 2009;24:2161-2169.

-16 Kistler AD, Mischak H, Poster D, Dakna M, Wuthrich RP, Serra AL: Identification of a unique urinary biomarker profile in patients with autosomal dominant polycystic kidney disease. Kidney Int 2009;76:89-96.

17 Lapolla A, Seraglia R, Molin L, Williams K, Cosma C, Reitano R, Sechi A, Ragazzi E, Traldi P: Low molecular weight proteins in urines from healthy subjects as well as diabetic, nephropathic and diabetic-nephropathic patients: a MALDI study. J Mass Spectrom 2009;44:419-425.

18 Quintana LF, Campistol JM, Alcolea MP, Banon-Maneus E, Sol-Gonzalez A, Cutillas PR: Application of label-free quantitative peptidomics for the identification of urinary biomarkers of kidney chronic allograft dysfunction. Mol Cell Proteomics 2009;8: 1658-1673.

19 Rossing K, Mischak H, Parving HH, Christensen PK, Walden M, Hillmann M, Kaiser T: Impact of diabetic nephropathy and angiotensin II receptor blockade on urinary polypeptide patterns. Kidney Int 2005;68: 193-205.

$20 \mathrm{Wu}$ J, Wang N, Wang J, Xie Y, Li Y, Liang T, Wang J, Yin Z, He K, Chen X: Identification of a uromodulin fragment for diagnosis of IgA nephropathy. Rapid Commun Mass Spectrom 2010;24:1971-1978.

-21 Ling XB, Sigdel TK, Lau K, Ying L, Lau I, Schilling J, Sarwal MM: Integrative urinary peptidomics in renal transplantation identifies biomarkers for acute rejection. J Am Soc Nephrol 2010;21:646-653.

-22 Sigdel TK, Kaushal A, Gritsenko M, Norbeck AD, Qian WJ, Xiao W, Camp DG, Smith RD, Sarwal MM: Shotgun proteomics identifies proteins specific for acute renal transplant rejection. Proteomics Clin Appl 2010;4:3247.
-23 Tamm I, Horsfall FL Jr: Characterization and separation of an inhibitor of viral hemagglutination present in urine. Proc Soc Exp Biol Med 1950;74:106-108.

24 Tamm I, Horsfall FL Jr: A mucoprotein derived from human urine which reacts with influenza, mumps, and Newcastle disease viruses. J Exp Med 1952;95:71-97.

25 Gottschalk A: Carbohydrate residue of a urine mucoprotein inhibiting influenza virus haemagglutination. Nature 1952;170: 662-663.

26 Maxfield M: Physicochemical study in water of a mucoprotein with virus-inhibiting activity. Science 1958;128:1087-1088.

27 Odin L: Carbohydrate residue of a urine mucoprotein inhibiting influenza virus hemagglutination. Nature 1952;170:663-664.

28 Porter KR, Tamm I: Direct visualization of a mucoprotein component of urine. J Biol Chem 1955;212:135-140.

29 Tamm I, Bugher JC, Horsfall FL, Jr: Ultracentrifugation studies of a urinary mucoprotein which reacts with various viruses. J Biol Chem 1955;212:125-133.

30 Curtain CC: The viscometric behaviour of a mucoprotein isolated from human urine. Aust J Exp Biol Med Sci 1953;31:255-265.

31 Bayer ME: An electron microscope examination of urinary mucoprotein and its interaction with influenza virus. J Cell Biol 1964;21: 265-274.

32 Bettelheim FA: Physical chemistry of mucins. Ann NY Acad Sci 1963;106:247-258.

33 Friedmann T, Johnson P: Further characterization of the subunit of Tamm-Horsfall mucoprotein. Biochim Biophys Acta 1966;130: 355-360.

34 Friedmann T, Johnson P: The disaggregation of Tamm Horsfall mucroprotein by acetic acid. Biochim Biophys Acta 1966;121:292297.

35 King JS Jr, Fielden ML, Boyce WH: Total nondialyzable solids in human urine. XI. Chemical analysis of purified normal uromucoid. Arch Biochem Biophys 1961;95: 424-427.

36 Maxfield M: Molecular forms of human urinary mucoprotein present under physiological conditions. Biochim Biophys Acta 1961; 49:548-558.

37 Maxfield M, Stefanye D: The amino acid composition of normal human urinary mucoprotein. J Biol Chem 1962;237:2522-2524.

38 Stevenson FK: The viscosity of Tamm-Horsfall mucoprotein. Biochim Biophys Acta 1968;160:296-298.

39 Rozenfel'd EL, Iusipova NA: A study of composition and properties of Tamm-Horsefall glycoprotein (in Russian). Biokhimiia 1967; 32:111-118.

40 Schwartz RH, Pallavicini JC: Immunologic and chemical studies of cystic fibrosis and normal urinary glycoprotein of Tamm and Horsfall. J Lab Clin Med 1967;70:725-735.
41 Fletcher AP, McLaughlin JE, Ratcliffe WA, Woods DA: The chemical composition and electron microscopic appearance of a protein derived from urinary casts. Biochim Biophys Acta 1970;214:299-308.

42 Fletcher AP, Neuberger A, Ratcliffe WA: Tamm-Horsfall urinary glycoprotein. The subunit structure. Biochem J 1970;120:425432.

-43 Fletcher AP, Neuberger A, Ratcliffe WA: Tamm-Horsfall urinary glycoprotein. The chemical composition. Biochem J 1970;120: 417-424.

-44 Oliver CJ, Pike ER, Cleave AJ, Peacocke AR: Determination of the diffusion coefficient and molecular weight of Tamm-Horsfall glycoprotein by intensity fluctuation spectroscopy. Biopolymers 1971;10:1731-1733.

45 Stevenson FK, Kent PW: Subunits of TammHorsfall glycoprotein. Biochem J 1970;116: 791-796.

-46 Jovine L, Qi H, Williams Z, Litscher E, Wassarman PM: The ZP domain is a conserved module for polymerization of extracellular proteins. Nat Cell Biol 2002;4:457-461.

47 Wiggins RC: Uromucoid (Tamm-Horsfall glycoprotein) forms different polymeric arrangements on a filter surface under different physicochemical conditions. Clin Chim Acta 1987;162:329-340.

-48 Monis B, Gomez A, Candiotti A, Ibenez N: The Tamm-Horsfall glycoprotein and the urinary system. Electrophoretic and electron microscopic observations. Life Sci II 1972;11:699-708.

- 49 McQueen EG, Engel GB: Factors determining the aggregation of urinary mucoprotein. J Clin Pathol 1966;19:392-396.

50 Jovine L, Janssen WG, Litscher ES, Wassarman PM: The PLAC1-homology region of the ZP domain is sufficient for protein polymerisation. BMC Biochem 2006;7:11

-51 Schaeffer C, Santambrogio S, Perucca S, Casari G, Rampoldi L: Analysis of uromodulin polymerization provides new insights into the mechanisms regulating ZP domainmediated protein assembly. Mol Biol Cell 2009;20:589-599.

52 Dawnay AB, Thornley C, Cattell WR: An improved radioimmunoassay for urinary Tamm-Horsfall glycoprotein. Investigation and resolution of factors affecting its quantification. Biochem J 1982;206:461-465.

53 Cornelius CE, Pangborn J, Heckly RJ: Isolation and characterization of a urinary mucoprotein from ovine urine. Arch Biochem Biophys 1963;101:403-408.

-54 Marr AM, Neuberger A, Ratcliffe WA: Rabbit Tamm-Horsfall urinary glycoprotein. Chemical composition and subunit structure. Biochem J 1971;122:623-631.

55 van Dijk W, Lasthuis AM, Ferwerda W: Preparation and chemical characterisation of calf Tamm-Horsfall glycoprotein. Biochim Biophys Acta 1979;584:121-128. 
56 Wallace AC, Nairn RC: Tamm-Horsfall protein in kidneys of human embryos and foreign species. Pathology 1971;3:303-310.

- 57 Dunstan DR, Grant AM, Marshall RD, Neuberger A: A protein, immunologically similar to Tamm-Horsfall glycoprotein, produced by cultured baby hamster kidney cells. Proc R Soc Lond B Biol Sci 1974;186: 297-316.

-58 Muchmore AV, Decker JM: Uromodulin: a unique 85-kilodalton immunosuppressive glycoprotein isolated from urine of pregnant women. Science 1985;229:479-481.

59 Muchmore AV: Uromodulin: an immunoregulatory glycoprotein isolated from pregnancy urine that binds to and regulates the activity of interleukin 1. Am J Reprod Immunol Microbiol 1986;11:89-93.

60 Muchmore AV, Decker JM: Uromodulin. An immunosuppressive 85-kilodalton glycoprotein isolated from human pregnancy urine is a high affinity ligand for recombinant interleukin 1 alpha. J Biol Chem 1986; 261:13404-13407.

-61 Brown KM, Muchmore AV, Rosenstreich DL: Uromodulin, an immunosuppressive protein derived from pregnancy urine, is an inhibitor of interleukin 1. Proc Natl Acad Sci USA 1986;83:9119-9123.

-62 Muchmore AV, Decker JM: Evidence that recombinant IL 1 alpha exhibits lectin-like specificity and binds to homogeneous uromodulin via $\mathrm{N}$-linked oligosaccharides. J Immunol 1987;138:2541-2546.

-63 Muchmore AV, Shifrin S, Decker JM: In vitro evidence that carbohydrate moieties derived from uromodulin, an 85,000 dalton immunosuppressive glycoprotein isolated from human pregnancy urine, are immunosuppressive in the absence of intact protein. J Immunol 1987;138:2547-2553.

64 Pennica D, Kohr WJ, Kuang WJ, Glaister D, Aggarwal BB, Chen EY, Goeddel DV: Identification of human uromodulin as the TammHorsfall urinary glycoprotein. Science 1987; 236:83-88.

65 Zhu X, Cheng J, Gao J, Lepor H, Zhang ZT, Pak J, Wu XR: Isolation of mouse THP gene promoter and demonstration of its kidneyspecific activity in transgenic mice. Am J Physiol Renal Physiol 2002;282:F608-F617.

66 Kim HT, Song IY, Piedrahita J: Kidney-specific activity of the bovine uromodulin promoter. Transgenic Res 2003;12:191-201.

-67 Huang YJ, Chretien N, Bilodeau AS, Zhou JF, Lazaris A, Karatzas CN: Goat uromodulin promoter directs kidney-specific expression of GFP gene in transgenic mice. BMC Biotechnol 2005;5:9.

- 68 Zbikowska HM, Soukhareva N, Behnam R, Chang R, Drews R, Lubon H, Hammond D, Soukharev S: The use of the uromodulin promoter to target production of recombinant proteins into urine of transgenic animals. Transgenic Res 2002;11:425-435.
69 Hamlin LM, Fish WW: Physical properties of Tamm-Horsfall glycoprotein and its glycopolypeptide. Int J Pept Protein Res 1977; 10:270-276.

70 Rampoldi L, Caridi G, Santon D, Boaretto F, Bernascone I, Lamorte G, Tardanico R, Dagnino M, Colussi G, Scolari F, Ghiggeri GM, Amoroso A, Casari G: Allelism of MCKD, FJHN and GCKD caused by impairment of uromodulin export dynamics. Hum Mol Genet 2003;12:3369-3384.

71 Tinschert S, Ruf N, Bernascone I, Sacherer K Lamorte G, Neumayer HH, Nurnberg P, Luft FC, Rampoldi L: Functional consequences of a novel uromodulin mutation in a family with familial juvenile hyperuricaemic nephropathy. Nephrol Dial Transplant 2004; 19:3150-3154.

72 Scolari F, Caridi G, Rampoldi L, Tardanico R, Izzi C, Pirulli D, Amoroso A, Casari G, Ghiggeri GM: Uromodulin storage diseases: clinical aspects and mechanisms. Am J Kidney Dis 2004;44:987-999.

73 Lens XM, Banet JF, Outeda P, Barrio-Lucia $\mathrm{V}$ : A novel pattern of mutation in uromodulin disorders: autosomal dominant medullary cystic kidney disease type 2, familial juvenile hyperuricemic nephropathy, and autosomal dominant glomerulocystic kidney disease. Am J Kidney Dis 2005;46:52-57.

74 Yang $\mathrm{H}, \mathrm{Wu} \mathrm{C}$, Zhao S, Guo J: Identification and characterization of D8C, a novel domain present in liver-specific LZP, uromodulin and glycoprotein 2 , mutated in familial juvenile hyperuricaemic nephropathy. FEBS Lett 2004;578:236-238.

75 van Rooijen JJ, Voskamp AF, Kamerling JP, Vliegenthart JF: Glycosylation sites and sitespecific glycosylation in human TammHorsfall glycoprotein. Glycobiology 1999;9: 21-30.

76 Brown DA, Rose JK: Sorting of GPIanchored proteins to glycolipid-enriched membrane subdomains during transport to the apical cell surface. Cell 1992;68:533-544.

77 Benting JH, Rietveld AG, Simons K: N-Glycans mediate the apical sorting of a GPI-anchored, raft-associated protein in MadinDarby canine kidney cells. J Cell Biol 1999; 146:313-320.

78 Hoyer JR, Sisson SP, Vernier RL: TammHorsfall glycoprotein: ultrastructural immunoperoxidase localization in rat kidney. Lab Invest 1979;41:168-173.

79 Gokhale JA, McKee MD, Khan SR: Immunocytochemical localization of Tamm-Horsfall protein in the kidneys of normal and nephrolithic rats. Urol Res 1996;24:201-209.

- 80 Vylet'al P, Hulkova H, Zivna M, Berna L, Novak P, Elleder M, Kmoch S: Abnormal expression and processing of uromodulin in Fabry disease reflects tubular cell storage alteration and is reversible by enzyme replacement therapy. J Inherit Metab Dis 2008;31: 508-517.
81 Kumar S, Jasani B, Hunt JS, Moffat DB, Asscher AW: A system for accurate immunolocalization of Tamm-Horsfall protein in renal biopsies. Histochem J 1985;17:1251-1258.

82 McKenzie JK, McQueen EG: Immunofluorescent localization of Tamm-Horsfall mucoprotein in human kidney. J Clin Pathol 1969:22:334-339.

83 Pollak VE, Arbel C: The distribution of Tamm Horsfall mucoprotein (uromucoid) in the human nephron. Nephron 1969;6:667-672.

84 Schenk EA, Schwartz RH, Lewis RA: TammHorsfall mucoprotein. I. Localization in the kidney. Lab Invest 1971;25:92-95.

85 Sikri KL, Foster CL, MacHugh N, Marshall RD: Localization of Tamm-Horsfall glycoprotein in the human kidney using immuno-fluorescence and immuno-electron microscopical techniques. J Anat 1981;132: 597-605.

86 Friedman T: Immunofluorescent localization of Tamm-Horsfall mucoprotein. Experientia 1966;22:624-625.

87 Bichler KH, Ideler V, Harzmann R: Uromucoid excretion in normal individuals and stone formers. Curr Probl Clin Biochem 1979:309-324.

- 88 Peach RJ, Day WA, Ellingsen PJ, McGiven AR: Ultrastructural localization of TammHorsfall protein in human kidney using immunogold electron microscopy. Histochem J 1988:20:156-164.

89 Hoyer JR, Sisson SP, Vernier RL: Immunoelectron microscopical localization of Tamm-Horsfall protein (THP) in rat kidney. Federation Proceedings 1978;37:837.

90 Bachmann S, Koeppen-Hagemann I, Kriz W: Ultrastructural localization of TammHorsfall glycoprotein (THP) in rat kidney as revealed by protein A-gold immunocytochemistry. Histochemistry 1985;83:531-538.

91 Jennings P, Aydin S, Kotanko P, Lechner J, Lhotta K, Williams S, Thakker RV, Pfaller W: Membrane targeting and secretion of mutant uromodulin in familial juvenile hyperuricemic nephropathy. J Am Soc Nephrol 2007;18:264-273.

-92 Dawnay A, McLean C, Cattell WR: The development of a radioimmunoassay for Tamm-Horsfall glycoprotein in serum. Biochem J 1980;185:679-687.

-93 Serafini-Cessi F, Bellabarba G, Malagolini N, Dall'Olio F: Rapid isolation of TammHorsfall glycoprotein (uromodulin) from human urine. J Immunol Methods 1989;120: 185-189.

-94 Shenoi J, Kurien BT, Kurono S, Mascarenhas R, Matsumoto H, Scofield RH: Cost-benefit analysis of a method using diatomaceous earth to purify Tamm-Horsfall protein. Biotechniques 2004;36:64-66.

95 Cavallone D, Malagolini N, Frasca GM, Stefoni S, Serafini-Cessi F: Salt-precipitation method does not isolate to homogeneity Tamm-Horsfall glycoprotein from urine of proteinuric patients and pregnant women. Clin Biochem 2002;35:405-410. 
96 Dahan K, Devuyst O, Smaers M, Vertommen D, Loute G, Poux JM, Viron B, Jacquot C, Gagnadoux MF, Chauveau D, Buchler M, Cochat P, Cosyns JP, Mougenot B, Rider $\mathrm{MH}$, Antignac C, Verellen-Dumoulin C, Pirson Y: A cluster of mutations in the UMOD gene causes familial juvenile hyperuricemic nephropathy with abnormal expression of uromodulin. J Am Soc Nephrol 2003;14:2883-2893.

$\checkmark 97$ Bleyer AJ, Hart TC, Shihabi Z, Robins V, Hoyer JR: Mutations in the uromodulin gene decrease urinary excretion of Tamm-Horsfall protein. Kidney Int 2004;66:974-977.

-98 Vylet'al P, Kublova M, Kalbacova M, Hodanova K, Baresova V, Stiburkova B, Sikora J, Hulkova H, Zivny J, Majewski J, Simmonds A, Fryns JP, Venkat-Raman G, Elleder M, Kmoch S: Alterations of uromodulin biology: a common denominator of the genetically heterogeneous FJHN/MCKD syndrome. Kidney Int 2006;70:1155-1169.

$\checkmark 99$ Zimmerhackl LB, Pfleiderer S, Kinne R, Manz F, Schuler G, Brandis M: Tamm-Horsfall-Protein excretion as a marker of ascending limb transport indicates early renal tubular damage in diabetes mellitus type I. J Diabet Complications 1991;5:112-114.

100 Uto I, Ishimatsu T, Hirayama H, Ueda S, Tsuruta J, Kambara T: Determination of urinary Tamm-Horsfall protein by ELISA using a maleimide method for enzyme-antibody conjugation. J Immunol Methods 1991;138:87-94.

-101 Kjellsson B, Soderstrom T, Hanson LA: An ELISA method for quantification of TammHorsfall protein using monoclonal antibodies. J Immunol Methods 1987;98:105-111.

-102 Hunt JS, Peach RJ, Brunisholz MC, Lynn KL, McGiven AR: A sensitive and specific ELISA using a monoclonal capture antibody for detection of Tamm-Horsfall urinary glycoprotein in serum. J Immunol Methods 1986;91:35-43.

103 Alfaham M, Peters TJ, Meyrick S, Avis P, Verrier Jones K: Serum Tamm-Horsfall protein levels in childhood: relationship with age and glomerular filtration rate. Nephron 1989;52:216-221.

104 Grant AM, Neuberger A: The development of a radioimmunoassay for the measurement of urinary Tamm-Horsfall glycoprotein in the presence of sodium dodecyl sulphate. Clin Sci 1973;44:163-179.

105 Avis PJ: The development of a radioimmunoassay procedure for the estimation of Tamm-Horsfall glycoprotein in human serum. Clin Sci Mol Med 1977;52:183-191.

106 Goodall AA, Marshall RD: Effects of freezing on the estimated amounts of TammHorsfall glycoprotein in urine, as determined by radioimmunoassay. Biochem J 1980;189:533-539.

-107 Lynn KL, Shenkin A, Marshall RD: Factors affecting excretion of human urinary Tamm-Horsfall glycoprotein. Clin Sci (Lond) 1982;62:21-26.
108 Yu M, Zhu YQ: Clinical significance of determination of urinary albumin, beta $2 \mathrm{mi}$ croglobulin and Tamm-Horsfall protein in diabetics (in Chinese). Zhonghua Nei Ke Za Zhi 1991;30:354-356, 383.

109 Gambaro G, Baggio B, Favaro S, Cicerello E, Marchini F, Borsatti A: Role of TammHorsfall mucoprotein in calcium oxalate lithogenesis (in French). Nephrologie 1984; 5:171-172.

110 Haugen H, Akesson I, Enger E, Meberg A: Uromucoid in normal urine. Scand J Clin Lab Invest 1978;38:49-51.

111 Bichler KH, Kirchner C, Ideler V: Uromucoid excretion of normal individuals and stone formers. Br J Urol 1975;47:733-737.

112 Samuell CT: Uromucoid excretion in normal subjects, calcium stone formers and in patients with chronic renal failure. Urol Res 1979;7:5-12.

113 Shihabi ZK, Hinsdale ME, Bleyer AJ: Analysis of Tamm-Horsfall protein by high-performance liquid chromatography with native fluorescence. J Chromatogr A 2004; 1027:161-166.

114 Yokomizo K, Iijima S, Sakai N, Kurihara Y, Hitratsuka N, Nagai K, Iwai T, Shiba K: Urinary protein analysis in pre- and postoperative cancer patients. J Clin Lab Anal 2005;19:253-259.

115 Wai-Hoe L, Wing-Seng L, Ismail Z, LayHarn G: SDS-PAGE-based quantitative assay for screening of kidney stone disease. Biol Proced Online 2009;11:145-160.

116 Pourmand G, Nasseh H, Sarrafnejad A, Mojtahedi A, Mehrsai A, Alamdari DH, Nourijelyani K: Comparison of urinary proteins in calcium stone formers and healthy individuals: a case-control study. Urol Int 2006;76:163-168.

117 Bernascone I, Vavassori S, Di Pentima A Santambrogio S, Lamorte G, Amoroso A, Scolari F, Ghiggeri GM, Casari G, Polishchuk R, Rampoldi L: Defective intracellular trafficking of uromodulin mutant isoforms. Traffic 2006;7:1567-1579.

118 Dahan K, Fuchshuber A, Adamis S, Smaers M, Kroiss S, Loute G, Cosyns JP, Hildebrandt F, Verellen-Dumoulin C, Pirson Y: Familial juvenile hyperuricemic nephropathy and autosomal dominant medullary cystic kidney disease type 2: two facets of the same disease? J Am Soc Nephrol 2001; 12:2348-2357.

119 Bleyer AJ, Hart TC, Willingham MC, Iskandar SS, Gorry MC, Trachtman H: Clinico-pathologic findings in medullary cystic kidney disease type 2. Pediatr Nephrol 2005;20:824-827.

120 Choi SW, Ryu OH, Choi SJ, Song IS, Bleyer AJ, Hart TC: Mutant Tamm-Horsfall glycoprotein accumulation in endoplasmic reticulum induces apoptosis reversed by colchicine and sodium 4-phenylbutyrate. J Am Soc Nephrol 2005;16:3006-3014.
121 Paladino S, Pocard T, Catino MA, Zurzolo C: GPI-anchored proteins are directly targeted to the apical surface in fully polarized MDCK cells. J Cell Biol 2006;172:10231034.

122 Rajendran L, Simons K: Lipid rafts and membrane dynamics. J Cell Sci 2005;118: 1099-1102.

123 Hoyer JR, Seiler MW: Pathophysiology of Tamm-Horsfall protein. Kidney Int 1979; 16:279-289.

124 Sabharanjak S, Sharma P, Parton RG, Mayor S: GPI-anchored proteins are delivered to recycling endosomes via a distinct cdc42regulated, clathrin-independent pinocytic pathway. Dev Cell 2002;2:411-423.

125 Kirkham M, Fujita A, Chadda R, Nixon SJ, Kurzchalia TV, Sharma DK, Pagano RE, Hancock JF, Mayor S, Parton RG: Ultrastructural identification of uncoated caveolin-independent early endocytic vehicles. J Cell Biol 2005;168:465-476.

126 Zaucke F, Boehnlein JM, Steffens S, Polishchuk RS, Rampoldi L, Fischer A, Pasch A, Boehm CW, Baasner A, Attanasio M, Hoppe B, Hopfer H, Beck BB, Sayer JA, Hildebrandt F, Wolf MT: Uromodulin is expressed in renal primary cilia and UMOD mutations result in decreased ciliary uromodulin expression. Hum Mol Genet 2010; 19:1985-1997.

127 Pak J, Pu Y, Zhang ZT, Hasty DL, Wu XR: Tamm-Horsfall protein binds to type 1 fimbriated Escherichia coli and prevents E. coli from binding to uroplakin Ia and Ib receptors. J Biol Chem 2001;276:9924-9930.

128 Orskov I, Ferencz A, Orskov F: TammHorsfall protein or uromucoid is the normal urinary slime that traps type 1 fimbriated Escherichia coli. Lancet 1980;1:887.

129 Parkkinen J, Virkola R, Korhonen TK: Identification of factors in human urine that inhibit the binding of Escherichia coli adhesins. Infect Immun 1988;56:2623-2630.

130 Glauser A, Hochreiter W, Jaeger P, Hess B: Determinants of urinary excretion of Tamm-Horsfall protein in non-selected kidney stone formers and healthy subjects. Nephrol Dial Transplant 2000;15:15801587.

131 Grover PK, Moritz RL, Simpson RJ, Ryall RL: Inhibition of growth and aggregation of calcium oxalate crystals in vitro - a comparison of four human proteins. Eur J Biochem 1998;253:637-644.

132 Hess B, Nakagawa Y, Coe FL: Inhibition of calcium oxalate monohydrate crystal aggregation by urine proteins. Am J Physiol 1989;257:F99-F106

133 Worcester EM: Urinary calcium oxalate crystal growth inhibitors. J Am Soc Nephrol 1994;5:S46-S53.

134 Beshensky AM, Wesson JA, Worcester EM, Sorokina EJ, Snyder CJ, Kleinman JG: Effects of urinary macromolecules on hydroxyapatite crystal formation. J Am Soc Nephrol 2001;12:2108-2116. 
-135 Kumar V, Farell G, Lieske JC: Whole urinary proteins coat calcium oxalate monohydrate crystals to greatly decrease their adhesion to renal cells. J Urol 2003;170:221225.

-136 Kumar V, Pena de la Vega L, Farell G, Lieske JC: Urinary macromolecular inhibition of crystal adhesion to renal epithelial cells is impaired in male stone formers. Kidney Int 2005;68:1784-1792.

-137 Gersch MS, Sautin YY, Gersch CM, Henderson G, Bankir L, Johnson RJ: Does TammHorsfall protein-uric acid binding play a significant role in urate homeostasis? Nephrol Dial Transplant 2006;21:2938-2942.

138 Diamond HS, Paolino JS: Evidence for a postsecretory reabsorptive site for uric acid in man. J Clin Invest 1973;52:1491-1499.

-139 Podevin R, Ardaillou R, Paillard F, Fontanelle J, Richet G: Study in man of the kinetics of the appearance of uric acid 2-14C in the urine (in French). Nephron 1968;5:134140.

-140 Podevin R, Paillard F, Hornych A, Ardaillou R, Fontanelle J, Richet G: Kinetics of the appearance in the urine of para-aminohippuric acid (PAH) and of $2-14 \mathrm{C}$ uric acid in man. Effects of benziodarone, acetylsalicylic acid and pyrazinamide (in French). Rev Fr Etud Clin Biol 1968;13:513-522.

- 141 Bates JM, Raffi HM, Prasadan K, Mascarenhas R, Laszik Z, Maeda N, Hultgren SJ, Kumar S: Tamm-Horsfall protein knockout mice are more prone to urinary tract infection: rapid communication. Kidney Int 2004;65:791-797.

-142 Mo L, Zhu XH, Huang HY, Shapiro E, Hasty DL, Wu XR: Ablation of the TammHorsfall protein gene increases susceptibility of mice to bladder colonization by type 1-fimbriated Escherichia coli. Am J Physiol Renal Physiol 2004;286:F795-F802.

-143 Raffi HS, Bates JM Jr, Laszik Z, Kumar S: Tamm-Horsfall protein acts as a general host-defense factor against bacterial cystitis. Am J Nephrol 2005;25:570-578.

-144 Raffi HS, Bates JM, Jr., Laszik Z, Kumar S: Tamm-Horsfall protein protects against urinary tract infection by proteus mirabilis. J Urol 2009;181:2332-2338.

-145 Mo L, Huang HY, Zhu XH, Shapiro E, Hasty DL, Wu XR: Tamm-Horsfall protein is a critical renal defense factor protecting against calcium oxalate crystal formation. Kidney Int 2004;66:1159-1166.

- 146 El-Achkar TM, Wu XR, Rauchman M, McCracken R, Kiefer S, Dagher PC: TammHorsfall protein protects the kidney from ischemic injury by decreasing inflammation and altering TLR4 expression. Am J Physiol Renal Physiol 2008;295:F534-F544.

- 147 Bachmann S, Mutig K, Bates J, Welker P, Geist B, Gross V, Luft FC, Alenina N, Bader M, Thiele BJ, Prasadan K, Raffi HS, Kumar S: Renal effects of Tamm-Horsfall protein (uromodulin) deficiency in mice. Am J Physiol Renal Physiol 2005;288:F559-F567.
148 Gersch M, Mutig K, Bachmann S, Kumar S, Ouyang X, Johnson R: Is salt-wasting the long awaited answer to the hyperuricaemia seen in uromodulin storage diseases? Nephrol Dial Transplant 2006;21:20282029.

149 Dan T, Tanaka H, Koga H: Mechanism of uricosuric action of AA-193 in DBA/2N mice. J Pharmacol Exp Ther 1990;253:437443.

150 Hoyer JR: Tubulointerstitial immune complex nephritis in rats immunized with Tamm-Horsfall protein. Kidney Int 1980; 17:284-292.

151 Seiler MW, Hoyer JR: Ultrastructural studies of tubulointerstitial immune complex nephritis in rats immunized with TammHorsfall protein. Lab Invest 1981;45:321327.

152 Mayrer AR, Kashgarian M, Ruddle NH, Marier R, Hodson CJ, Richards FF, Andriole VT: Tubulointerstitial nephritis and immunologic responses to Tamm-Horsfall protein in rabbits challenged with homologous urine or Tamm-Horsfall protein. J Immunol 1982;128:2634-2642.

153 Sherblom AP, Decker JM, Muchmore AV: The lectin-like interaction between recombinant tumor necrosis factor and uromodulin. J Biol Chem 1988;263:5418-5424.

154 Rhodes DC, Hinsman EJ, Rhodes JA: Tamm-Horsfall glycoprotein binds IgG with high affinity. Kidney Int 1993;44: 1014-1021.

155 Su SJ, Chang KL, Lin TM, Huang YH, Yeh TM: Uromodulin and Tamm-Horsfall protein induce human monocytes to secrete TNF and express tissue factor. J Immunol 1997;158:3449-3456.

156 Cavallone D, Malagolini N, Serafini-Cessi F: Binding of human neutrophils to cellsurface anchored Tamm-Horsfall glycoprotein in tubulointerstitial nephritis. Kidney Int 1999;55:1787-1799.

157 Ratliff TL: Tamm-Horsfall glycoprotein links innate immune cell activation with adaptive immunity via a Toll-like receptor4-dependent mechanism. J Urol 2005;174: 1150.

158 Toma G, Bates JM, Jr., Kumar S: Uromodulin (Tamm-Horsfall protein) is a leukocyte adhesion molecule. Biochem Biophys Res Commun 1994;200:275-282.

159 Hession C, Decker JM, Sherblom AP, Kumar S, Yue CC, Mattaliano RJ, Tizard R, Kawashima E, Schmeissner U, Heletky S, et al: Uromodulin (Tamm-Horsfall glycoprotein): a renal ligand for lymphokines. Science 1987;237:1479-1484.

160 Benetti E, Caridi G, Vella MD, Rampoldi L, Ghiggeri GM, Artifoni L, Murer L: Immature renal structures associated with a novel UMOD sequence variant. Am J Kidney Dis 2009;53:327-331.
161 Bleyer AJ, Trachtman H, Sandhu J, Gorry MC, Hart TC: Renal manifestations of a mutation in the uromodulin (Tamm Horsfall protein) gene. Am J Kidney Dis 2003; 42:E20-E26.

162 Calado J, Gaspar A, Clemente C, Rueff J: A novel heterozygous missense mutation in the UMOD gene responsible for familial juvenile hyperuricemic nephropathy. BMC Med Genet 2005;6:5.

163 Kudo E, Kamatani N, Tezuka O, Taniguchi A, Yamanaka H, Yabe S, Osabe D, Shinohara S, Nomura K, Segawa M, Miyamoto T, Moritani M, Kunika K, Itakura M: Familial juvenile hyperuricemic nephropathy: detection of mutations in the uromodulin gene in five Japanese families. Kidney Int 2004;65:1589-1597.

164 Lhotta K, Gehringer A, Jennings P, Kronenberg F, Brezinka C, Andersone I, Strazdins V: Familial juvenile hyperuricemic nephropathy: report on a new mutation and a pregnancy. Clin Nephrol 2009;71:80-83.

165 Nasr SH, Lucia JP, Galgano SJ, Markowitz GS, D’Agati VD: Uromodulin storage disease. Kidney Int 2008;73:971-976.

166 Williams SE, Reed AA, Galvanovskis J, Antignac C, Goodship T, Karet FE, Kotanko P, Lhotta K, Moriniere V, Williams P, Wong W, Rorsman P, Thakker RV: Uromodulin mutations causing familial juvenile hyperuricaemic nephropathy lead to protein maturation defects and retention in the endoplasmic reticulum. Hum Mol Genet 2009;18:2963-2974.

167 Wolf MT, Beck BB, Zaucke F, Kunze A, Misselwitz J, Ruley J, Ronda T, Fischer A, Eifinger F, Licht C, Otto E, Hoppe B, Hildebrandt F: The uromodulin C744G mutation causes MCKD2 and FJHN in children and adults and may be due to a possible founder effect. Kidney Int 2007;71:574-581.

168 Wolf MT, Mucha BE, Attanasio M, Zalewski I, Karle SM, Neumann HP, Rahman N, Bader B, Baldamus CA, Otto E, Witzgall R, Fuchshuber A, Hildebrandt F: Mutations of the uromodulin gene in MCKD type 2 patients cluster in exon 4, which encodes three EGF-like domains. Kidney Int 2003;64: 1580-1587.

169 Stiburkova B, Majewski J, Sebesta I, Zhang W, Ott J, Kmoch S: Familial juvenile hyperuricemic nephropathy: localization of the gene on chromosome 16p11.2- and evidence for genetic heterogeneity. Am J Hum Genet 2000;66:1989-1994

170 Auranen M, Ala-Mello S, Turunen JA, Jarvela I: Further evidence for linkage of autosomal-dominant medullary cystic kidney disease on chromosome 1q21. Kidney Int 2001;60:1225-1232.

-171 Puig JG, Prior C, Martinez-Ara J, Torres RJ: Familial nephropathy associated with hyperuricemia in Spain: our experience with 3 families harbouring a UMOD mutation. Nucleosides Nucleotides Nucleic Acids 2006;25:1295-1300. 
-172 Stiburkova B, Majewski J, Hodanova K, Ondrova L, Jerabkova M, Zikanova M, Vylet'al P, Sebesta I, Marinaki A, Simmonds A, Matthijs G, Fryns JP, Torres R, Puig JG, Ott J, Kmoch S: Familial juvenile hyperuricaemic nephropathy (FJHN): linkage analysis in 15 families, physical and transcriptional characterisation of the FJHN critical region on chromosome 16 p11.2 and the analysis of seven candidate genes. Eur J Hum Genet 2003;11:145-154.

173 Hodanova K, Majewski J, Kublova M, Vyletal P, Kalbacova M, Stiburkova B, Hulkova $\mathrm{H}$, Chagnon YC, Lanouette CM, Marinaki A, Fryns JP, Venkat-Raman G, Kmoch S: Mapping of a new candidate locus for uromodulin-associated kidney disease (UAKD) to chromosome 1q41. Kidney Int 2005;68:1472-1482.

- 174 Zivna M, Hulkova H, Matignon M, Hodanova K, Vylet'al P, Kalbacova M, Baresova V, Sikora J, Blazkova H, Zivny J, Ivanek R, Stranecky V, Sovova J, Claes K, Lerut E, Fryns JP, Hart PS, Hart TC, Adams JN, Pawtowski A, Clemessy M, Gasc JM, Gubler MC, Antignac C, Elleder M, Kapp K, Grimbert P, Bleyer AJ, Kmoch S: Dominant renin gene mutations associated with early-onset hyperuricemia, anemia, and chronic kidney failure. Am J Hum Genet 2009;85:204213.

- 175 Bingham C, Ellard S, van't Hoff WG, Simmonds HA, Marinaki AM, Badman MK, Winocour PH, Stride A, Lockwood CR, Nicholls AJ, Owen KR, Spyer G, Pearson ER, Hattersley AT: Atypical familial juvenile hyperuricemic nephropathy associated with a hepatocyte nuclear factor-1beta gene mutation. Kidney Int 2003;63:1645-1651.

- 176 Gresh L, Fischer E, Reimann A, Tanguy M, Garbay S, Shao X, Hiesberger T, Fiette L, Igarashi P, Yaniv M, Pontoglio M: A transcriptional network in polycystic kidney disease. EMBO J 2004;23:1657-1668.

177 Heidet L, Decramer S, Pawtowski A, Moriniere V, Bandin F, Knebelmann B, Lebre AS, Faguer S, Guigonis V, Antignac C, Salomon R: Spectrum of HNF1B mutations in a large cohort of patients who harbor renal diseases. Clin J Am Soc Nephrol 2010;5: 1079-1090.

-178 Takiue Y, Hosoyamada M, Yokoo T, Kimura M, Ochiai M, Kaneko K, Ichida K, Hosoya T, Shibasaki T: Production and characterization of transgenic mice harboring mutant human UMOD gene. Nucleosides Nucleotides Nucleic Acids 2008;27:596600.

-179 Takiue Y, Hosoyamada M, Yokoo T, Kimura M, Shibasaki T: Progressive accumulation of intrinsic mouse uromodulin in the kidneys of transgenic mice harboring the mutant human uromodulin gene. Biol Pharm Bull 2008;31:405-411.
180 Kemter E, Rathkolb B, Rozman J, Hans W, Schrewe A, Landbrecht C, Klaften M, Ivandic B, Fuchs H, Gailus-Durner V, Klingenspor M, de Angelis MH, Wolf E, Wanke R, Aigner B: Novel missense mutation of uromodulin in mice causes renal dysfunction with alterations in urea handling, energy, and bone metabolism. Am J Physiol Renal Physiol 2009;297:F1391-F1398.

181 Bernascone I, Janas S, Ikehata M, Trudu M Corbelli A, Schaeffer C, Rastaldi MP, Devuyst O, Rampoldi L: A transgenic mouse model for uromodulin-associated kidney diseases shows specific tubulo-interstitial damage, urinary concentrating defect and renal failure. Hum Mol Genet 2010;19:2998-3010.

182 Yusenko MV, Zubakov D, Kovacs G: Gene expression profiling of chromophobe renal cell carcinomas and renal oncocytomas by Affymetrix GeneChip using pooled and individual tumours. Int J Biol Sci 2009;5:517527.

183 Song X, Di Giovanni V, He N, Wang K, Ingram A, Rosenblum ND, Pei Y: Systems biology of autosomal dominant polycystic kidney disease (ADPKD): computational identification of gene expression pathways and integrated regulatory networks. Hum Mol Genet 2009; 18:2328-2343.

-184 Stickel JS, Weinzierl AO, Hillen N, Drews O, Schuler MM, Hennenlotter J, Wernet D, Muller CA, Stenzl A, Rammensee HG, Stevanovic S: HLA ligand profiles of primary renal cell carcinoma maintained in metastases. Cancer Immunol Immunother 2009; 58:1407-1417.

185 Lenburg ME, Liou LS, Gerry NP, Frampton GM, Cohen HT, Christman MF: Previously unidentified changes in renal cell carcinoma gene expression identified by parametric analysis of microarray data. BMC Cancer 2003;3:31.

186 Jones J, Otu H, Spentzos D, Kolia S, Inan M, Beecken WD, Fellbaum C, Gu X, Joseph M, Pantuck AJ, Jonas D, Libermann TA: Gene signatures of progression and metastasis in renal cell cancer. Clin Cancer Res 2005;11: 5730-5739.

187 Kort EJ, Farber L, Tretiakova M, Petillo D, Furge KA, Yang XJ, Cornelius A, Teh BT: The E2F3-Oncomir-1 axis is activated in Wilms' tumor. Cancer Res 2008;68:40344038.

188 Cifola I, Spinelli R, Beltrame L, Peano C, Fasoli E, Ferrero S, Bosari S, Signorini S, Rocco F, Perego R, Proserpio V, Raimondo F, Mocarelli P, Battaglia C: Genome-wide screening of copy number alterations and $\mathrm{LOH}$ events in renal cell carcinomas and integration with gene expression profile. Mol Cancer 2008;7:6
189 Furge KA, Chen J, Koeman J, Swiatek P, Dykema K, Lucin K, Kahnoski R, Yang XJ, Teh BT: Detection of DNA copy number changes and oncogenic signaling abnormalities from gene expression data reveals MYC activation in high-grade papillary renal cell carcinoma. Cancer Res 2007;67: 3171-3176.

$>190$ Higgins JP, Shinghal R, Gill H, Reese JH, Terris M, Cohen RJ, Fero M, Pollack JR, van de Rijn M, Brooks JD: Gene expression patterns in renal cell carcinoma assessed by complementary DNA microarray. Am J Pathol 2003;162:925-932.

191 Gumz ML, Zou H, Kreinest PA, Childs AC, Belmonte LS, LeGrand SN, Wu KJ, Luxon BA, Sinha M, Parker AS, Sun LZ, Ahlquist DA, Wood CG, Copland JA: Secreted frizzled-related protein 1 loss contributes to tumor phenotype of clear cell renal cell carcinoma. Clin Cancer Res 2007;13:4740-4749.

192 Boni JP, Leister C, Bender G, Fitzpatrick V, Twine N, Stover J, Dorner A, Immermann F, Burczynski ME: Population pharmacokinetics of CCI-779: correlations to safety and pharmacogenomic responses in patients with advanced renal cancer. Clin Pharmacol Ther 2005;77:76-89.

193 Austruy E, Cohen-Salmon M, Antignac C, Beroud C, Henry I, Nguyen VC, Brugieres L, Junien C, Jeanpierre C: Isolation of kidney complementary DNAs down-expressed in Wilms' tumor by a subtractive hybridization approach. Cancer Res 1993;53: 2888-2894.

194 Li CM, Kim CE, Margolin AA, Guo M, Zhu J, Mason JM, Hensle TW, Murty VV, Grundy PE, Fearon ER, D'Agati V, Licht JD, Tycko B: CTNNB1 mutations and overexpression of Wnt/beta-catenin target genes in WT1-mutant Wilms' tumors. Am J Pathol 2004;165:1943-1953.

-195 Kumar S, Marsden HB, Jasani B, Kumar P: Study of childhood renal tumours using a monoclonal antibody to Tamm-Horsfall protein. J Clin Pathol 1987;40:1456-1462.

196 Saint-Mezard P, Berthier CC, Zhang H, Hertig A, Kaiser S, Schumacher M, Wieczorek G, Bigaud M, Kehren J, Rondeau E, Raulf F, Marti HP: Analysis of independent microarray datasets of renal biopsies identifies a robust transcript signature of acute allograft rejection. Transpl Int 2009;22: 293-302.

197 Rodder S, Scherer A, Raulf F, Berthier CC, Hertig A, Couzi L, Durrbach A, Rondeau E, Marti HP: Renal allografts with IF/TA display distinct expression profiles of metzincins and related genes. Am J Transplant 2009;9:517-526.

198 Park WD, Stegall MD: A meta-analysis of kidney microarray datasets: investigation of cytokine gene detection and correlation with rt-PCR and detection thresholds. BMC Genomics 2007;8:88. 
199 Baelde HJ, Eikmans M, Doran PP, Lappin DW, de Heer E, Bruijn JA: Gene expression profiling in glomeruli from human kidneys with diabetic nephropathy. Am J Kidney Dis 2004;43:636-650.

200 Cvoriscec D, Stavljenic A: Correlation between urinary excretion of Tamm-Horsfall protein and sodium chloride in endemic nephropathy. J Trace Elem Electrolytes Health Dis 1988;2:205-207.

201 Thornley C, Dawnay A, Cattell WR: Human Tamm-Horsfall glycoprotein: urinary and plasma levels in normal subjects and patients with renal disease determined by a fully validated radioimmunoassay. Clin Sci (Lond) 1985;68:529-535.

-202 Ying WZ, Sanders PW: Dietary salt regulates expression of Tamm-Horsfall glycoprotein in rats. Kidney Int 1998;54:1150-1156.

-203 Mazzuchi N, Pecarovich R, Ross N, Rodriguez I, Sanguinetti CM: Tamm-Horsfall urinary glycoprotein quantitation by radial immunodiffusion: normal patterns. J Lab Clin Med 1974;84:771-776.

-204 Ollier-Hartmann MP, Pouget-Abadie C, Bouillie J, Hartmann L: Variations of urinary Tamm-Horsfall protein in humans during the first thirty years of life. Nephron 1984;38:163-166.

205 McKenzie JK, Patel R, McQueen EG: The excretion rate of Tamm-Horsfall urinary mucoprotein in normals and in patients with renal disease. Australas Ann Med 1964;13:32-39.

-206 Schwartz RH, Van Ess JD, May AG, Schenk EA, Freeman RB: Tamm-Horsfall glycoproteinuria and renal allograft rejection. Transplantation 1973;16:83-87.

207 Dulawa J, Kokot F, Kokot M, Pander H: Urinary excretion of Tamm-Horsfall protein in normotensive and hypertensive elderly patients. J Hum Hypertens 1998;12:635637.

-208 Sobel JD, Kaye D: Reduced uromucoid excretion in the elderly. J Infect Dis 1985;152: 653.

209 Grant AM, Neuberger A: The turnover rate of rabbit urinary Tamm-Horsfall glycoprotein. Biochem J 1973;136:659-668.

-210 Prajczer S, Heidenreich U, Pfaller W, Kotanko P, Lhotta K, Jennings P: Evidence for a role of uromodulin in chronic kidney disease progression. Nephrol Dial Transplant 2010;25:1896-1903.

-211 Sejdiu I, Torffvit O: Decreased urinary concentration of Tamm-Horsfall protein is associated with development of renal failure and cardiovascular death within 20 years in type 1 but not in type 2 diabetic patients. Scand J Urol Nephrol 2008;42:168-174.

-212 Holmquist P, Torffvit O: Tubular function in diabetic children assessed by TammHorsfall protein and glutathione S-transferase. Pediatr Nephrol 2008;23:1079-1083.

213 Kottgen A, Pattaro C, Boger CA, Fuchsberger C, Olden M, Glazer NL, Parsa A, Gao X, Yang Q, Smith AV, O'Connell JR, Li
M, Schmidt H, Tanaka T, Isaacs A, Ketkar S, Hwang SJ, Johnson AD, Dehghan A, Teumer A, Pare G, Atkinson EJ, Zeller T, Lohman K, Cornelis MC, Probst-Hensch NM, Kronenberg F, Tonjes A, Hayward C, Aspelund T, Eiriksdottir G, Launer LJ, Harris TB, Rampersaud E, Mitchell BD, Arking DE, Boerwinkle E, Struchalin M, Cavalieri M, Singleton A, Giallauria F, Metter J, de Boer IH, Haritunians T, Lumley T, Siscovick D, Psaty BM, Zillikens MC, Oostra BA, Feitosa M, Province M, de Andrade M, Turner ST, Schillert A, Ziegler A, Wild PS, Schnabel RB, Wilde S, Munzel TF, Leak TS, Illig T, Klopp N, Meisinger C, Wichmann HE, Koenig W, Zgaga L, Zemunik T, Kolcic I, Minelli C, Hu FB, Johansson A, Igl W, Zaboli G, Wild SH, Wright AF, Campbell $\mathrm{H}$, Ellinghaus D, Schreiber S, Aulchenko YS, Felix JF, Rivadeneira F, Uitterlinden AG, Hofman A, Imboden M, Nitsch D, Brandstatter A, Kollerits B, Kedenko L, Magi R, Stumvoll M, Kovacs P, Boban M, Campbell S, Endlich K, Volzke H, Kroemer HK, Nauck M, Volker U, Polasek O, Vitart V, Badola S, Parker AN, Ridker PM, Kardia SL, Blankenberg S, Liu Y, Curhan GC, Franke A, Rochat T, Paulweber B, Prokopenko I, Wang W, Gudnason V, Shuldiner AR, Coresh J, Schmidt R, Ferrucci L, Shlipak MG, van Duijn CM, Borecki I, Kramer BK, Rudan I, Gyllensten U, Wilson JF, Witteman JC, Pramstaller PP, Rettig R, Hastie N, Chasman DI, Kao WH, Heid IM, Fox CS: New loci associated with kidney function and chronic kidney disease. Nat

Genet 2010;42:376-384.

214 Chambers JC, Zhang W, Lord GM, van der Harst P, Lawlor DA, Sehmi JS, Gale DP, Wass MN, Ahmadi KR, Bakker SJL, Beckmann J, Bilo HJG, Bochud M, Brown MJ, Caulfield MJ, Connell JMC, Cook HT, Cotlarciuc I, Smith GD, de Silva R, Deng G, Devuyst O, Dikkeschei LD, Dimkovic N, Dockrell M, Dominiczak A, Ebrahim S, Eggermann T, Farrall M, Ferrucci L, Floege J, Forouhi NG, Gansevoort RT, Han X, Hedblad B, van der Heide JJH, Hepkema BG, Hernandez-Fuentes M, Hypponen E, Johnson T, de Jong PE, Kleefstra N, Lagou V, Lapsley M, Li Y, Loos RJF, Luan Ja, Luttropp K, Marechal C, Melander O, Munroe PB, Nordfors L, Parsa A, Peltonen L, Penninx BW, Perucha E, Pouta A, Prokopenko I, Roderick PJ, Ruokonen A, Samani NJ, Sanna S, Schalling M, Schlessinger D, Schlieper G, Seelen MAJ, Shuldiner AR, Sjogren M, Smit JH, Snieder H, Soranzo N, Spector TD, Stenvinkel P, Sternberg MJE, Swaminathan R, Tanaka T, Ubink-Veltmaat LJ, Uda M, Vollenweider P, Wallace C, Waterworth D, Zerres K, Waeber G, Wareham NJ, Maxwell $\mathrm{PH}$, McCarthy MI, Jarvelin M-R, Mooser V, Abecasis GR, Lightstone L, Scott J, Navis G, Elliott P, Kooner JS: Genetic loci influencing kidney function and chronic kidney disease. Nat Genet 2010;42:373-375.
215 Pattaro C, De Grandi A, Vitart V, Hayward C, Franke A, Aulchenko YS, Johansson A, Wild SH, Melville SA, Isaacs A, Polasek O, Ellinghaus D, Kolcic I, Nothlings U, Zgaga L, Zemunik T, Gnewuch C, Schreiber S, Campbell S, Hastie N, Boban M, Meitinger T, Oostra BA, Riegler P, Minelli C, Wright AF, Campbell H, van Duijn CM, Gyllensten U, Wilson JF, Krawczak M, Rudan I, Pramstaller PP: A meta-analysis of genome-wide data from five European isolates reveals an association of COL22A1, SYT1, and GABRR2 with serum creatinine level. BMC Med Genet 2010;11:41.

216 Quintana LF, Sole-Gonzalez A, Kalko SG, Banon-Maneus E, Sole M, Diekmann F, Gutierrez-Dalmau A, Abian J, Campistol JM: Urine proteomics to detect biomarkers for chronic allograft dysfunction. J Am Soc Nephrol 2009;20:428-435.

- 217 Pieper R, Gatlin CL, McGrath AM, Makusky AJ, Mondal M, Seonarain M, Field E, Schatz CR, Estock MA, Ahmed N, Anderson NG, Steiner S: Characterization of the human urinary proteome: a method for high-resolution display of urinary proteins on two-dimensional electrophoresis gels with a yield of nearly 1400 distinct protein spots. Proteomics 2004;4:1159-1174.

218 Lau WH, Leong WS, Ismail Z, Gam LH: Qualification and application of an ELISA for the determination of Tamm Horsfall protein (THP) in human urine and its use for screening of kidney stone disease. Int $\mathrm{J}$ Biol Sci 2008;4:215-222.

219 Khan SR, Canales BK: Genetic basis of renal cellular dysfunction and the formation of kidney stones. Urol Res 2009;37:169-180.

220 Weaver ML, Qiu SR, Hoyer JR, Casey WH, Nancollas GH, De Yoreo JJ: Surface aggregation of urinary proteins and aspartic acidrich peptides on the faces of calcium oxalate monohydrate investigated by in situ force microscopy. Calcif Tissue Int 2009;84:462-473.

221 Kokot M, Dulawa J, Nowicki M, Kokot F, Machowska J: Urinary excretion of TammHorsfall protein by patients with acute renal failure (in Polish). Pol Arch Med Wewn 1992;88:225-229.

222 Chen A, Zhao S, Huang S: Relationship between Syndrome-Type in TCM and four trace urinary proteins in patients with bronchial asthma (in Chinese). Zhongguo Zhong Xi Yi Jie He Za Zhi 1998;18:537-539.

-223 Cvoriscec D, Stavljenic A, Radonic M: Tamm-Horsfall protein in Balkan endemic nephropathy. J Clin Chem Clin Biochem 1985;23:177-181.

224 Raicevic S, Trnacevic S, Hranisavljevic J, Vucelic D: Renal function, protein excretion, and pathology of Balkan endemic nephropathy. II. Protein excretion. Kidney Int Suppl 1991;34:S52-S56.

225 Radonic M, Cvoriscec D, Borso G, Stavljenic A, Ceovic S: Tamm-Horsfall protein determination in Balkan endemic nephropathy. Urol Res 1988;16:377-380. 
226 Cvoriscec D, Stavljenic A, Radonic M: Relationship between tubular and Tamm-Horsfall proteinuria in Balkan endemic nephropathy. Nephron 1986;42:152-155.

227 Yang HC: Monitoring of renal function in burn patients with radioimmunological evaluation (in Chinese). Zhonghua Zheng Xing Shao Shang Wai Ke Za Zhi 1992;8: 288-290, 330.

-228 Grant AM, Baker LR, Neuberger A: Urinary Tamm-Horsfall glycoprotein in certain kidney diseases and its content in renal and bladder calculi. Clin Sci 1973;44:377384.

229 Kido T, Honda R, Tsuritani I, Ishizaki M, Yamada Y, Nakagawa H, Nogawa K: Significant increase of urinary mucoprotein in environmental-cadmium-exposed Japanese subjects. Toxicol Lett 1991;55:303309.

230 Jackle-Meyer I, Gwinner W, Baum M, Soose M, Petzoldt R, Schmoll HJ, Stolte H: Significance of Tamm-Horsfall protein excretion in diabetes mellitus and cisplatin nephrotoxicity. Contrib Nephrol 1990;83: 124-129.

-231 Zimmerhackl LB: Evaluation of nephrotoxicity with renal antigens in children: role of Tamm-Horsfall protein. Eur J Clin Pharmacol 1993;44(Suppl 1):S39-S42.

-232 MacLean FR, Skinner R, Hall AG, English $\mathrm{M}$, Pearson AD: Acute changes in urine protein excretion may predict chronic ifosfamide nephrotoxicity: a preliminary observation. Cancer Chemother Pharmacol 1998;41:413-416.

233 Dawnay A, Lucey MR, Thornley C, Beetham R, Neuberger JM, Cattell WR, Williams R: The effects of long-term, lowdose cyclosporine A on renal tubular function in humans. Transplant Proc 1988;20: $725-731$.

-234 Torffvit O, Jorgensen PE, Kamper AL, Holstein-Rathlou NH, Leyssac PP, Poulsen SS, Strandgaard S: Urinary excretion of TammHorsfall protein and epidermal growth factor in chronic nephropathy. Nephron 1998; 79:167-172.

-235 Holmquist P, Torffvit O, Jorgensen PE, Torring N, Nexo E, Sjoblad S: Early urinary changes in Tamm-Horsfall protein and epidermal growth factor in diabetic children. Pediatr Nephrol 2001;16:488-492.

-236 Mattyus I, Miltenyi M, Zimmerhackl LB, Schwarz A, Hentschel M, Brandis M, Tulassay T: Endothelin excretion during ketoacidosis does not correlate with tubular dysfunction. Pediatr Nephrol 1994;8:304-308.

-237 Torffvit O, Eriksson JW, Henricsson M, Sundkvist G, Arnqvist HJ, Blohme G, Bolinder J, Nystrom L, Ostman J, Svensson M: Early changes in glomerular size selectivity in young adults with type 1 diabetes and retinopathy. Results from the Diabetes Incidence Study in Sweden. J Diabetes Complications 2007;21:246-251.
238 Torffvit O, Agardh CD, Thulin T: A study of Tamm-Horsfall protein excretion in hypertensive patients and type 1 diabetic patients. Scand J Urol Nephrol 1999;33:187191.

239 Torffvit O, Agardh CD: Tubular secretion of Tamm-Horsfall protein is decreased in type 1 (insulin-dependent) diabetic patients with diabetic nephropathy. Nephron 1993;65:227-231.

240 Torffvit O: Urinary sulphated glycosaminoglycans and Tamm-Horsfall protein in type 1 diabetic patients. Scand J Urol Nephrol 1999;33:328-332.

241 Torffvit O, Agardh CD, Kjellsson B, Wieslander J: Tubular secretion of TammHorsfall protein in type 1 (insulin-dependent) diabetes mellitus using a simplified enzyme linked immunoassay. Clin Chim Acta 1992;205:31-41.

242 Torffvit O, Agardh CD: Urinary excretion rate of $\mathrm{NCl}$ and Tamm-Horsfall protein in the microalbuminuric type I diabetic patient. J Diabetes Complications 1994;8:7783.

243 Pfleiderer S, Zimmerhackl LB, Kinne R, Manz F, Schuler G, Brandis M: Renal proximal and distal tubular function is attenuated in diabetes mellitus type 1 as determined by the renal excretion of alpha 1-microglobulin and Tamm-Horsfall protein. Clin Investig 1993;71:972-977.

244 Catalano C, Torffvit O: Urinary excretion of Tamm-Horsfall protein in normotensive, normo-albuminuric type 1 diabetic patients. Nephron 1996;72:436-441.

245 Below AA, Chakraborty J, Khuder SH, Haselhuhn GD: Evaluation of urinary Tamm-Horsfall protein in post-menopausal diabetic women. J Diabetes Complications 1999;13:204-210.

246 Bernard AM, Ouled AA, Lauwerys RR, Lambert A, Vandeleene B: Pronounced decrease of Tamm-Horsfall proteinuria in diabetics. Clin Chem 1987;33:1264.

-247 Reinhart HH, Obedeanu N, Robinson R, Korzeniowski O, Kaye D, Sobel JD: Urinary excretion of Tamm-Horsfall protein in elderly women. J Urol 1991;146:806-808.

248 Cutillas PR, Chalkley RJ, Hansen KC, Cramer R, Norden AG, Waterfield MD, Burlingame AL, Unwin RJ: The urinary proteome in Fanconi syndrome implies specificity in the reabsorption of proteins by renal proximal tubule cells. Am J Physiol Renal Physiol 2004;287:F353-F364.

249 Vilasi A, Cutillas PR, Maher AD, Zirah SF, Capasso G, Norden AW, Holmes E, Nicholson JK, Unwin RJ: Combined proteomic and metabonomic studies in three genetic forms of the renal Fanconi syndrome. Am J Physiol Renal Physiol 2007;293:F456-F467.

250 Schroter J, Timmermans G, Seyberth HW Greven J, Bachmann S: Marked reduction of Tamm-Horsfall protein synthesis in hyperprostaglandin E-syndrome. Kidney Int 1993;44:401-410.
251 Dulawa J, Kokot M, Kokot F: Effects of furosemide, propranolol and nifedipine on urinary excretion of Tamm-Horsfall protein in patients with arterial hypertension (in Polish). Pol Arch Med Wewn 1992;88: 212-218.

252 Bade JJ, Marrink J, Karrenbeld A, van der Weele L, Mensink HJ: Increased urinary levels of Tamm-Horsfall glycoprotein suggest a systemic etiology of interstitial cystitis. J Urol 1996;156:943-946.

253 Canter MP, Graham CA, Heit MH, Blackwell LS, Wilkey DW, Klein JB, Merchant ML: Proteomic techniques identify urine proteins that differentiate patients with interstitial cystitis from asymptomatic control subjects. Am J Obstet Gynecol 2008; 198:553.e1-e6.

254 Dawnay AB, Thornley C, Nockler I, Webb JA, Cattell WR: Tamm-Horsfall glycoprotein excretion and aggregation during intravenous urography. Relevance to acute renal failure. Invest Radiol 1985;20:53-57.

-255 Ehrlich R, Robins T, Jordaan E, Miller S, Mbuli S, Selby P, Wynchank S, Cantrell A, De Broe M, D’Haese P, Todd A, Landrigan P: Lead absorption and renal dysfunction in a South African battery factory. Occup Environ Med 1998;55:453-460.

-256 Pergande M, Jung K, Precht S, Fels LM, Herbort C, Stolte H: Changed excretion of urinary proteins and enzymes by chronic exposure to lead. Nephrol Dial Transplant 1994;9:613-618

257 Yokomizoi K, Nakayama A, Hokazono E, Ninomiya A, Miyake R, Hiratsuka N, Okuyama M, Kato Y, Kobayashi S, Ito Y, Shiba K: Analysis of proteins in urinary tract stones and urine of urolithic patients (in Japanese). Rinsho Byori 2005;53:11091115.

258 Singh P, Pendse A, Rajkiran, Rajkiran, Partani B: Diurnal variations and $24 \mathrm{hr}$ urinary excretion of mucoprotein and Tamm-Horsfall protein in renal stone patients. Indian J Clin Biochem 1993;8:54-58.

259 Duława J, Drab M, Drobisz M, Kokot F: Urinary excretion of Tamm-Horsfall protein in healthy subjects and patients with renal disease. Nieren Hochdruckkrankheiten 1993;22:110-113.

260 Singhal GD, Singh DN, Gopal SC, Ambasta SS, Gupta RM: Urinary mucoprotein in pediatric urolithiasis. J Pediatr Surg 1987;22: 218-222.

-261 Wai-Hoe L, Wing-Seng L, Ismail Z, LayHarn G: Proteomics and detection of uromodulin in first-time renal calculi patients and recurrent renal calculi patients. Appl Biochem Biotechnol 2009; 159:221-232.

262 Boyce WH, Swanson M: Biocolloids of urine in health and in calculous disease. II. Electrophoretic and biochemical studies of a mucoprotein insoluble in molar sodium chloride. J Clin Invest 1955;34:1581-1589. 
263 Ganter K, Bongartz D, Hesse A: TammHorsfall protein excretion and its relation to citrate in urine of stone-forming patients. Urology 1999;53:492-495.

264 Laube N, Glatz S, Hesse A: The relation of urinary Tamm-Horsfall-protein on $\mathrm{CaOx}-$ crystallization under the scope of the Bonn-Risk-Index. Urol Res 2001;29:45-49.

-265 Scurr DS, Latif AB, Sergeant V, Robertson WG: Polyanionic inhibitors of calcium oxalate crystal agglomeration in urine. Proc Eur Dial Transplant Assoc 1983;20:440444.

-266 Baggio B, Gambaro G, Favaro S, Borsatti A, Pavanello L, Siviero B, Zacchello G, Rizzoni GF: Juvenile renal stone disease: a study of urinary promoting and inhibiting factors. J Urol 1983;130:1133-1135.

267 Sophasan S, Chatasingh S, Thanphaichitr P, Dhanamitta S: Tamm Horsfall mucoprotein in urine of potential bladder stone formers. J Urol 1980;124:522-524.

-268 Bichler KH, Henzler B, Strohmaier WL, Stahl C, Korn S: The significance of citrate, uromucoid and GAG for diagnosis of renal tubular acidosis in patients with urinary calculi (in German). Urologe A 1995;34: 437-443.

269 Romero MC, Nocera S, Nesse AB: Decreased Tamm-Horsfall protein in lithiasic patients. Clin Biochem 1997;30:63-67.

270 Jaggi M, Nakagawa Y, Zipperle L, Hess B: Tamm-Horsfall protein in recurrent calcium kidney stone formers with positive family history: abnormalities in urinary excretion, molecular structure and function. Urol Res 2007;35:55-62.

-271 Bichler K, Mittermüller B, Strohmaier WL, Feil G, Eipper E: Excretion of Tamm-Horsfall protein in patients with uric acid stones. Urol Int 1999;62:87-92.

-272 Tsai CY, Wu TH, Yu CL, Lu JY, Tsai YY: Increased excretions of beta2-microglobulin, IL-6, and IL-8 and decreased excretion of Tamm-Horsfall glycoprotein in urine of patients with active lupus nephritis. Nephron 2000;85:207-214.

-273 Cardenas A, Roels H, Bernard AM, Barbon R, Buchet JP, Lauwerys RR, Rosello J, Hotter G, Mutti A, Franchini I, et al: Markers of early renal changes induced by industrial pollutants. I. Application to workers exposed to mercury vapour. $\mathrm{Br} \mathrm{J}$ Ind Med 1993;50:17-27.

274 Meberg A, Haugen H, Akesson I, Sande H: Uromucoid (Tamm-Horsfall's mucoprotein) in amniotic fluid and in urine in children. Nephron 1979;23:28-31.

-275 Voss JU, Roller M, Brinkmann E, Mangelsdorf I: Nephrotoxicity of organic solvents: biomarkers for early detection. Int Arch Occup Environ Health 2005;78:475-485.

276 Bruning T, Thier R, Mann H, Melzer H, Brode P, Dallner G, Bolt HM: Pathological excretion patterns of urinary proteins in miners highly exposed to dinitrotoluene. J Occup Environ Med 2001;43:610-615.
-277 Mutti A, Alinovi R, Bergamaschi E, Biagini C, Cavazzini S, Franchini I, Lauwerys RR, Bernard AM, Roels H, Gelpi E, et al: Nephropathies and exposure to perchloroethylene in dry-cleaners. Lancet 1992;340: 189-193.

278 Jablonski K, Bauer A, Karolak A, Dobryszycka W: Urinary mucoprotein fractions and 17-ketosteroids in healthy women and in patients with the stein-leventhal syndrome. Arch Immunol Ther Exp (Warsz) 1969;17:253-260.

279 Nesselhut T, Rath W, Grunow E, Kaufholz G, Ostermai U, Cillien N, Kuhn W: The relationship between urinary Tamm-Horsfall glycoprotein excretion and urinary activity of glycosidases in normal pregnancy and pre-eclampsia. Eur J Obstet Gynecol Reprod Biol 1993;48:23-31.

280 Nesselhut T, Rath W, Weber MH, Kuhn W: Changes in Tamm-Horsfall protein excretion in the urine of patients with hypertension in pregnancy (in German). Klin Wochenschr 1989;67(Suppl 17):11-13.

281 Franek E, Bar A, Kokot F, Dulawa J, Wiecek A, Kochanska-Dziurowicz A, Bar K, Szkodny A, Pawlowski W, Myrta J: Abnormal function of renal tubules in patients with simple renal cysts. Int Urol Nephrol 1995; 27:679-685.

282 Lynn KL, Marshall RD: Excretion of Tamm-Horsfall glycoprotein in renal disease. Clin Nephrol 1984;22:253-257.

283 Nakagawa Y: Urinary Tamm-Horsfall glycoprotein in patients with various renal diseases. Nippon Jinzo Gakkai Shi 1987;29: 529-534.

284 Shiba KS, Kanamori K, Harada T, Nakao M, Nakajima K, Kodaira T, Nakagawa H: A cause of discrepancy between values for urinary protein as assayed by the Coomassie Brilliant Blue G-250 method and the sulfosalicylic acid method. Clin Chem 1985; 31:1215-1218.

285 Wikiera-Magott I, Hurkacz M, KilisPstrusinska K, Zielinska M, Zwolinska D, Orzechowska-Juzwenko K: Evaluation of renal function in children undergoing surgery under general anaesthesia (in Polish). Pol Merkur Lekarski 2002;13:212-215.

286 Dehne MG, Sablotzki A, Muhling J, Papke G, Kuntzsch U, Hempelmann G: Acute kidney failure. Non-invasive diagnosis of acute kidney failure in operative intensive care patients (in German). Anaesthesist 1998;47: 193-201.

-287 Aregger F, Pilop C, Uehlinger DE, Brunisholz R, Carrel TP, Frey FJ, Frey BM: Urinary proteomics before and after extracorporeal circulation in patients with and without acute kidney injury. J Thorac Cardiovasc Surg 2010;139:692-700.

288 Dehne MG, Boldt J, Heise D, Sablotzki A, Hempelmann G: Tamm-Horsfall protein, alpha-1- and beta-2-microglobulin as kidney function markers in heart surgery (in German). Anaesthesist 1995;44:545-551.
289 Dehne MG, Sablotzki A, Muhling J, Dehne KL, Rohrig R, Hempelmann G: Renal effects of cardiopulmonary bypass in the elderly. Perfusion 2002;17:205-209.

290 Torffvit O, Kamper AL, Strandgaard S: Tamm-Horsfall protein in urine after uninephrectomy/transplantation in kidney donors and their recipients. Scand J Urol Nephrol 1997;31:555-559.

291 Kaden J, Groth J, May G, Liedvogel B: Urinary Tamm-Horsfall protein as a marker of renal transplant function. Urol Res 1994; 22:131-136.

-292 McLaughlin PJ, Aikawa A, Davies HM, Ward RG, Bakran A, Sells RA, Johnson PM: Uromodulin levels are decreased in urine during acute tubular necrosis but not during immune rejection after renal transplantation. Clin Sci (Lond) 1993;84:243-246.

293 Patzer L, Hempel L, Ringelmann F, Misselwitz J, Fuchs D, Zintl F, Brandis M, deBroe ME, Zimmerhackl LB: Renal function after conditioning therapy for bone marrow transplantation in childhood. Med Pediatr Oncol 1997;28:274-283.

294 Franek E, Bar A, Kokot F, Dulawa J, Wiecek A, Kochanska-Dziurowicz A, Bar K, Szkodny A, Pawlowski W, Myrta J: Concentrations of B2-microglobulin and TammHorsfall protein in cyst fluid and urinary excretion of these proteins in patients with simple renal cysts (in Polish). Pol Arch Med Wewn 1994;92:107-115.

295 Patzer L, Ringelmann F, Kentouche K, Fuchs D, Zintl F, Brandis M, Zimmerhackl LB, Misselwitz J: Renal function in longterm survivors of stem cell transplantation in childhood. A prospective trial. Bone Marrow Transplant 2001;27:319-327.

296 Romero MC, Zanaro N, Gonzalez L, Trigo P, Imventarza O, Nesse A: Tamm-Horsfall protein excretion to predict the onset of renal insufficiency. Clin Biochem 2002;35: 65-68.

297 Lose G, Sorensen K, Frandsen B, Nathan E: Excretion of urinary Tamm-Horsfall glycoprotein in girls with recurrent urinary tract infections. Urol Res 1987;15:249-250.

-298 Reinhart HH, Spencer JR, Zaki NF, Sobel JD: Quantitation of urinary Tamm-Horsfall protein in children with urinary tract infection. Eur Urol 1992;22:194-199.

299 Reinhart H, Obedeanu N, Hooton T, Stamm W, Sobel J: Urinary excretion of Tamm-Horsfall protein in women with recurrent urinary tract infections. J Urol 1990;144:1185-1187.

300 Wolska-Duda I, Dulawa J, Kokot F: Urinary excretion of Tamm-Horsfall protein, albumin and beta- 2 microglobulin in children with recurrent urinary tract infection (in Polish). Pol Merkur Lekarski 2001;11:36-39.

301 Israele V, Darabi A, McCracken GH Jr: The role of bacterial virulence factors and Tamm-Horsfall protein in the pathogenesis of Escherichia coli urinary tract infection in infants. Am J Dis Child 1987;141:1230-1234. 